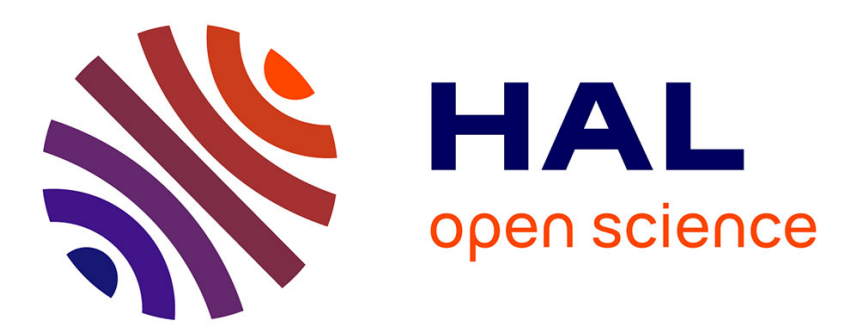

\title{
Paving the way for better telecom performance: Evidence from the telecommunication sector in MENA countries
}

\author{
Riham Ahmed Ezzat
}

\section{- To cite this version:}

Riham Ahmed Ezzat. Paving the way for better telecom performance: Evidence from the telecommunication sector in MENA countries. 2015. halshs-01164199

\section{HAL Id: halshs-01164199 \\ https://shs.hal.science/halshs-01164199}

Submitted on 16 Jun 2015

HAL is a multi-disciplinary open access archive for the deposit and dissemination of scientific research documents, whether they are published or not. The documents may come from teaching and research institutions in France or abroad, or from public or private research centers.
L'archive ouverte pluridisciplinaire HAL, est destinée au dépôt et à la diffusion de documents scientifiques de niveau recherche, publiés ou non, émanant des établissements d'enseignement et de recherche français ou étrangers, des laboratoires publics ou privés. 


\section{Documents de Travail du

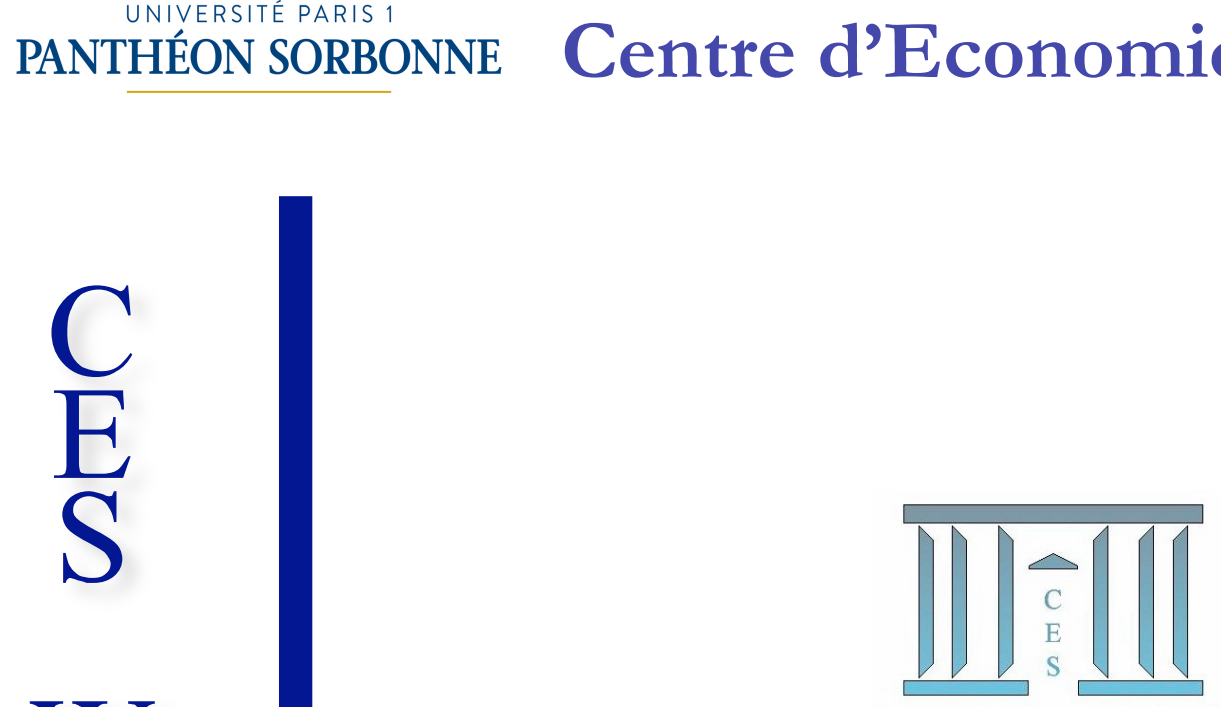

Paving the way for better telecom performance:

Evidence from the telecommunication sector in MENA countries

Riham AHMED EZZAT

2015.39

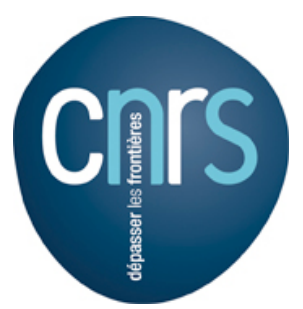

Maison des Sciences Économiques, 106-112 boulevard de L'Hôpital, 75647 Paris Cedex 13 http://centredeconomiesorbonne.univ-paris 1.fr/ 


\title{
Paving the way for better telecom performance: Evidence from the telecommunication sector in MENA countries
}

\author{
Riham AHMED EZZAT ${ }^{1}$
}

\begin{abstract}
Since the 1980s, developing countries started adopting telecom reforms due to pressures from international institutions. However, Middle East and North African (MENA) countries lagged in adopting such reforms. Even after introducing telecom reforms in the MENA region beginning in 1995, not all countries became better off in terms of various performance indicators. Therefore, this paper empirically assesses the effects of regulation, privatization and liberalization reforms, as well as their simultaneous presences, in the telecommunication sector on the sector's performance using a sample of 17 MENA countries for the period 1995-2010. We assume that different reforms are affected by institutional, political and economic variables with respect to the level of democracy, the legal origin, the natural resources rents per country and the year of independence from colonization. We correct for the endogeneity of telecom reforms, and we use IV-2SLS (Instrumental Variable-Two Stages Least Squares) estimation to analyze their effect on telecom performance in terms of access, productivity and affordability. We find that the privatization of the main incumbent operator and the fixed-line market's liberalization affect the sector's performance negatively in terms of fixed access and affordability. Moreover, we find that the simultaneous presence of an independent regulator and a privatized incumbent helps to eliminate the drawbacks on the sector performance resulting from privatization. However, the simultaneous presences of the other reforms in terms of regulation-competition and privatization-fixed competition do not help to improve the sector's performance.
\end{abstract}

Keywords Regulation. Privatization. Competition. Telecom industry. MENA region

JEL Classification L11 . L14 . L33 . L43 . L51 . L96 . O38 . O50

R. Ahmed Ezzat

$\mathrm{PhD}$ candidate at the Centre d'Economie de la Sorbonne, Université Paris 1 Panthéon-Sorbonne and Assistant Lecturer of Economics at the Faculty of Economics and Political Science, Cairo University.

E-mail: riham.ahmedezzat@gmail.com 


\section{Introduction}

The telecommunication sector widely developed across the world beginning in the 1980s thanks to technological, institutional, regulatory and demand-side developments. The telecommunication industry is regarded as the most economically significant and politically sensitive industry being privatized in the world today (Bortolotti et al. 2002). After 1990, the regulatory framework had largely evolved, and many countries opened their sector to competition. At the current stage of development of the telecommunication sector, it is still concerned with issues related to the triptych "regulation (reregulation), privatization and liberalization" (Joskow 2007). Given these three telecommunication reforms, policymakers need to identify the best practice by which to reform the telecommunication sector, which should be analyzed within the institutional and political contexts of the countries studied. Although the regulatory framework of the telecommunication industry has changed radically since the 1980s, much remains to be accomplished, especially in developing countries. This paper shows that the adoption of such reforms in a group of developing countries, under WB and IMF recommendations, does not guarantee the development of an efficient sector. As stated by Laffont (2005), the advisers repeated the percepts designed for developed countries while they paid little attention to the unique characteristics of the developing countries. Such characteristics include the inefficiency of their tax systems, their inability to audit costs, their inefficient credit markets, their widespread corruption, their inability to enter into long-term contracts with continuous renegotiations, the weakness they experience in administering the rule of law and their poor enforcement of laws and contracts. All of these characteristics are likely to harden the government's investment in the infrastructure, to affect the cost of public intervention, specifically in terms of regulation and competition policy and to make it difficult to attract the foreign capital that is necessary for the sector's development (Laffont 2005).

In the developing world, the telecom sector was the first infrastructure sector to be subject to major reforms, followed by the electricity sector. Such reforms were justified by its low performance, lack of investments and major inefficiencies. In addition, the aim of such reforms was to increase the investment level in the sector by giving investors more guarantees for operating in the market (Spiller 1993). Due to pressures from international institutions, mainly from the International Monetary Fund (IMF) and the World Bank (WB), developing countries have privatized their state-owned incumbent operators, allowing the entry of foreign and domestic operators to increase competition and establishing independent regulatory institutions. However, liberalization and deregulation failed to attract local or foreign investment.

Although there is a large movement toward regulatory reform in developing countries, the timing and features of the telecom reforms differ relatively across such countries. Since the 1980s, most developing countries started creating their independent regulatory authorities (IRAs). The establishment of IRAs became necessary, specifically after the market's liberalization, to ensure effective telecom markets by overseeing the incumbent behavior and serving as a credible safeguard for investors. For instance, some Latin American countries created their IRAs in the 1980s, such as those established in Argentina and Brazil, among others. For the Middle East and North African (MENA) countries, the adoption of telecom reforms was delayed; the first independent regulatory authority was established in Jordan in 1995. The adoption of telecom reforms in the MENA region took place mostly after their participation in the General Agreement on Trade in Services "GATS" had occurred. MENA countries also differ in their degrees of reform adoption: some are adopting telecom reforms; others, as was the case with most of the GCC countries, lagged in adopting such reforms. Such differences would help us to test the effect of different telecom reforms on the sector's performance.

The specificity of the MENA region is emphasized by the challenges faced by different MENA countries. Among those challenges are structural reforms, including reforming inefficient regulatory frameworks and the inadequate provisioning of infrastructure services. The absence of significant economic reforms and persistent political and macroeconomic instability is likely to keep investment and growth below its potential in developing the MENA region, in the short run as well as in the upcoming future, unless there is a break with past practices (World Bank 2013). Moreover, the region's persistent political instability has affected the investments in a negative manner by skewing them

\footnotetext{
${ }^{2}$ GATS is an international trade agreement in the context of World Trade Organization (WTO) agreements. The GATS aims to remove gradually all barriers to trade in services.
} 
toward the activities that create the fewest jobs. It is important to carry out reforms that are designed to overhaul the developmental paradigm. Another challenge faced by the MENA region is the adoption of an economic integration and reform program while taking into account the institutional features of such countries. The importance of the Greater Arab Free Trade Area (GAFTA) agreement notwithstanding, the MENA countries still need to go further and adopt an agreement including all MENA countries, which would be a measure serving to help wider and deeper integration among them.

Thus, among the most effective ways to develop a long-term strategy for better growth and employment for the MENA region is to create a competitive private environment to promote the FDI inflows and portfolio flows at the global level—particularly in the services sector. The MENA region's economic growth is likely to happen by addressing competition, privatization, regional integration, openness of new markets, and filling infrastructure gaps, among other approaches. In spite of the relative openness of the telecom sector, generally, to competition, the MENA region lagged in adopting reforms compared to other countries. Moreover, up until now, the MENA countries are still functioning below their potentials with respect to telecom market liberalization, which affects ICT development and the overall growth rate. The liberalization of services between the MENA countries is a measure that could help to facilitate further integration. Such liberalization would remove intra-regional services barriers and would facilitate more trade liberalization and higher economic growth via greater regional integration.

Therefore, the political, economic and institutional characteristics of the MENA countries shape their decisions in adopting reforms. To better understand the determinants of the telecom reforms, it is crucial to take into account the institutional and political framework for the MENA countries. It is noteworthy that, even after introducing different telecom reforms since 1995, not all MENA countries became better off in terms of different performance indicators ${ }^{3}$. Although the MENA countries outperformed Latin American and East Asian and Pacific countries in 1995 in terms of their fixed-line penetration, they showed more limited development and lagged behind them in 2011, which is not the case for mobile penetration. Hence, does the adoption of reforms in the MENA region improve or worsen the sector's performance? It is important to test the relationship between different telecom reforms and the sector's performance, given the economic, political and institutional characteristics of the MENA countries.

During this last decade, telecommunication reforms in developing countries have been heavily explored (Boylaud and Nicoletti 2000; Fink et al. 2001; Wallsten 2001; Fink et al. 2003; Estache et al. 2006; Gasmi et al. 2013). Although the MENA region is politically relevant, especially for Europe, the literature that focuses on the MENA countries is indeed scarce. No econometric study has explored the impact of telecom reforms on the sector's performance in the MENA countries ${ }^{4}$. Previous studies have been dedicated to Asian or Latin American countries that started reforming their sectors somewhat before the MENA countries. The slow pace of economic reforms and the lack of response of domestic and foreign investment to economic reform over the past two decades have thus been serious causes for concern for the MENA countries (Karshenas 1994). Because the MENA region lacks studies, specifically empirical studies, on the importance of telecom reforms and telecom service liberalization, despite being a sector vital in its contributions to economic and social development; our study is important for policymakers seeking to be aware of different gains and limits with regard to the effects of reforms and liberalization. Nevertheless, to the best of our knowledge, other than the study by Gual and Trillas $(2006)^{5}$ that takes into account the cross-sectional data on institutional endowment for 37 countries (3 MENA countries included), we can barely find studies that account for the countries' institutional characteristics. In this study, we assess whether imposing telecom reforms depends on the institutional, political and economic nature of such countries, or if the reforms are only due to pressures from the IMF and the WB, regardless the countries specificities. Accordingly, we are looking forward to focusing on original and non-traditional determinants of the adoption of reforms that have somehow tended to be overlooked in previous studies; such determinants will be used as instruments for different

\footnotetext{
${ }^{3}$ See the Appendix and Table 2.

${ }^{4}$ Rossotto et al. (2005) state that the market liberalization in the MENA region has been slower than elsewhere in the developing world. They develop an indicator of market openness that encompasses elements of competition, openness to FDI and regulatory independence for the MENA region. However, the empirical evidence they provide is not specific to MENA countries.

${ }^{5}$ They collected a number of political variables on the general quality of the government, interest groups, ideologies, institutions and traditions of each country with regard to the state's involvement in the economy.
} 
reforms. We principally use the level of democracy, the legal origin, the natural resources rents per country while controlling for the year of independence from colonization for each country.

Accordingly, this paper aims to develop an empirical analysis for 17 MENA countries ${ }^{6}$ from 19952010 to explore the impact of telecom reforms, as well as the simultaneous presence of different reforms on telecom performance in the voice market for the fixed and the mobile segments. For instance, does the simultaneous adoption of privatization and market liberalization help to improve the sector's performance? Does the simultaneous establishment of an IRA with privatization or market liberalization matter for better sector performance? Finally, does the simultaneous presence of the three reforms help to improve MENA telecom performance? The starting date of the study was chosen according to the beginning of the adoption of most of the telecom reforms in the MENA countries, and also according to the availability of data. Namely, mobile services were introduced in the MENA countries in the late 1990s. A study of the effect of reforms sequences on the sector's performance is beyond the scope of this paper.

As main results, we find that the privatization of the incumbent operator and fixed-line market liberalization lead to reduced access and higher prices. Moreover, we find that having an independent regulator, while privatizing the incumbent operator, helps to eliminate drawbacks of privatization with regard to the sector's performance. However, having an independent regulator, when liberalizing the telecom sector, does not help to improve the sector's performance. Furthermore, opening the fixed sector for competition, when allowing the privatization of the incumbent operator, also does not matter. Finally, implementing the three reforms simultaneously helps to increase mobile access, telecom productivity and fixed prices, but it decreases fixed-line penetration.

The paper is organized as follows. Section 2 presents background on the MENA region's telecom sector to emphasize the issues at stake. The literature review and the testable hypotheses derived from the literature are presented in Section 3. Section 4 provides the data, the empirical model we adopt to test the hypotheses and the results. Section 5 presents a discussion of the different results. We end with concluding remarks in Section 6.

\section{Background and MENA telecom liberalization}

In this section, we aim to introduce MENA telecom reforms, as well as their level of telecom performance, to create an assessment before starting the empirical analysis. First, we introduce each telecom reform: regulation, privatization and liberalization, while describing the evolution of such reform in the case of the MENA region.

\subsection{The triptych of telecom reforms in the MENA region}

For the developing world, major reforms are introduced under pressure from the IMF and the WB in order to reschedule debt service payments or to solicit new loans in the contexts of new stabilization and adjustment agreements. These consist of moving towards greater trade liberalization, extensive liberalization of price controls and removal of government trading monopolies. Overall, the low performance of the telecom sector in the MENA region was not the only driver of adopting reforms; the conditions that guided the reforms were mostly political. Until 1995, the telecom sector in the MENA region suffered from the inertia of its traditional structure; the incumbent operator was mostly a stateowned monopolistic operator ${ }^{7}$. Thus, the sector regulation was undertaken by the government with no independent regulator in place. The first independent regulatory authority - the Telecommunications Regulatory Commission (TRC)—was established in Jordan in 1995. (For a description of the IRA's

\footnotetext{
${ }^{6}$ The countries included are as follows: Algeria, Bahrain, Djibouti, Egypt, Jordan, Kuwait, Lebanon, Libya, Morocco, Oman, Qatar, Saudi Arabia, Sudan, Syria, Tunisia, the United Arab Emirates and Yemen. We exclude Iraq, Iran and Palestine due to the lack of consistent data for many variables over the entire period. Also, we exclude Israel and Turkey because they are considered to be developed countries (OECD countries).

${ }^{7}$ Three MENA incumbents were private before 1995: Batelco Bahrain was established in 1981, with Cable and Wireless taking a 40\% stake; Etisalat Emirates was privatized in 1983 (the government took a 60\% share in the company, whereas 40\% is publicly traded) and finally, Sudatel Sudan was privatized in 1994 (the government owned $66.7 \%$, and the private sector, 33.3\%).
} 
establishment, see Table 1.) Moreover, the incumbent operator was either regulated by the government and its ministers or it was self-regulated.

The first reform to be adopted by the group of MENA countries was the establishment of an independent regulatory authority ${ }^{8}$. Levy and Spiller (1994) state that regulatory independence is a necessary element for the regulator to be an effective institution and a credible safeguard for investors. According to Wallsten (2003), no matter what definition of independence is used, regulatory agencies will to some degree always be connected to the government. However, such separation reduces the probability of a regulatory capture, either by the government or by the operators. Hence, our focus in this paper would be to emphasize whether there exists an independent regulatory authority from its government or not. Actually, as shown in Table 1, 5 of the 17 MENA countries have no independent regulator. For Djibouti, Kuwait, and Yemen, the regulatory functions are the responsibility of the ministry of Communications. For Libya, the General Telecommunication Authority (GTA) has been the telecommunication regulatory body since 2006 , but it was headed by the son of Libya's former president. Finally, Syria's regulatory framework is the responsibility of the incumbent operator, the Syrian Telecommunication Establishment.

The second reform in the triptych concerns the privatization of the main incumbent operator. The move from state ownership to private ownership is usually regarded as a necessary condition for significant market liberalization (Parker and Saal 2003). According to the literature (Boycko et al. 1996; North 1990; Levy and Spiller 1996), the type of ownership affects firm behavior and performance, because the incentives faced by decision makers change according to the ownership type. For most of the MENA countries, the privatization of the incumbent operator started in approximately the late 1990s to the early 2000s. It is noteworthy that the privatization of the MENA region's telecom sector does not imply the loss of state control over the incumbent operator, because the state mostly maintained the largest share of the incumbent capital. As shown in Bortolotti et al. (2004), partial or incomplete sales are a common feature of the privatization process. For the MENA region, as of 2010, 10 of the 17 MENA countries had started the process of the incumbent privatization; 9 of them have partially privatized, and only one is fully privatized (Jordan). It is worth noting that many studies, such as that by Estache et al. (2006), considered the commitment to privatization as a proxy for the commitment to liberalization. In fact, even if the existence of private telecommunication companies is necessary, it is not a sufficient condition for increased competition. For instance, in the context of the MENA region, the incumbent operator was privatized in Jordan in 2000, and then, the fixed-line market was liberalized in 2005 in compliance with its GATS commitments. For Morocco, the incumbent operator-Maroc Telecom - was first privatized in 2001 by selling 35\% to Vivendi France, and then the fixed-line market was opened to Meditel and to Wana "Maroc Connect" in 2006 and 2007, respectively. Other countries introduced privatization of their incumbent operator but failed to foster competitive markets, as was the case in Egypt. The process of Telecom Egypt's privatization started in 2005. However, it remains incomplete because, in 2012, Telecom Egypt's shares were 80\% owned by the Egyptian Government, and $20 \%$ were in free float. Moreover, Egypt failed to foster a fixed competitive market. Thus, such privatization only creates a private monopoly. Hence, is it necessary to liberalize the market when allowing for the incumbent privatization? Would a competitive market limit the market power of a privatized monopoly?

The last telecom reform is market liberalization, which occurs by opening the sector for new operators. In this paper, we will focus on the competition that occurs in the provision of services, rather than the competition at the infrastructure level. Thus, we will study the effects of liberalization that occur in the service-based markets for the local fixed and mobile services. The liberalization framework is important because a monopoly, whether state-owned or privately owned, has fewer incentives to improve services and lower prices than a firm operating in a competitive environment. Even after the opening of the sector to competition, the incumbent Public Telecom Operator (PTO) still has a competitive advantage that can be exploited against new entrants because it has no incentive to share its network with new entrants or establish suitable interconnection terms. Consequently, when the government plays the role of regulator, as well as serves as the owner of the incumbent operator, even

\footnotetext{
${ }^{8}$ The regulatory framework in MENA countries has received considerable attention also in the energy sector due to the relevant exchanges with Europe; see Cambini and Franzi (2013), and Cambini and Rubino (2014).
} 
partially, the interconnection agreements would be in favor of the incumbent operator. As emphasized by Wallsten (2003), the incumbent operator can be a barrier to market liberalization. Hence, the solution is to have the simultaneous or prior presence of an IRA that would set the market rules and oversee the incumbent's behavior. For the MENA countries, in many cases specifically for the fixed-line market, potential entrants have been discouraged by the high set-up costs of establishing a new network. For example, Telecom Egypt has refused to lease its network to new market entrants, as was done by Morocco's incumbent in 2007 (Marouani and Munro 2009). Actually, competition in the MENA countries is greater in the mobile markets than in the fixed-line markets, which recently started to be liberalized. Moreover, even if the monopoly condition for the incumbent fixed operator has been lifted, there remain high barriers to entry, such as the cost of building a network, which requires sharing the incumbent's network with suitable interconnection terms. For many MENA countries, the fixed segment is still closed to competition, with 10 of 17 countries having a fixed monopoly market, which is not the case in the mobile market, where it is mostly competitive, as shown in Table 1.

\subsection{Telecom performance in the MENA region}

It is noteworthy that the MENA region differs compared with other developing regions, such as Latin America and the Caribbean (LAC) and East Asia and the Pacific (EAP) regions, in terms of telecom reforms and performance. Moreover, there is some degree of heterogeneity between the MENA countries in terms of their adoption of reforms, as we mentioned in the previous subsection, as well as in terms of their levels of telecom performance, with higher level being observed in the Gulf Cooperation Council (GCC) $)^{9}$ countries.

In 1995, the MENA countries showed a modest fixed-line penetration, with an average of 10.2 lines per 100 inhabitants, compared to 44.8 for OECD countries. Except for some GCC countries, the remaining MENA countries suffered from significantly lower fixed-line penetration, where limited network expansion could be justified by the large geographic size and lower level of income compared to most GCC countries. For example, fixed-line penetration for North African countries was approximately 3.8 lines per 100 people. In the light of the technological developments in telecommunications in the world economy, the modest performance of the telecom sector in the MENA countries highlighted the need for adopting different reforms. Fixed and mobile penetration indicators for the MENA countries in 2011 are depicted in Table 2. Between 1995 and 2011, the MENA countries witnessed an increase in fixed-line penetration from an average of 11.49 to 12.7 lines per 100 inhabitants, compared to 43.19 for OECD countries. This increase may be due either to a substitution effect between the fixed and mobile lines, to the development of mobile broadband compared with fixed broadband or to the dual-SIM effect. It is noteworthy that, although the LAC and EAP regions experienced modest fixed-line penetration in 1995 compared to the MENA countries, the evolution of their fixed-line penetrations in 2010 was much higher than for the MENA countries. There is no doubt that the telecom sector reforms carried out by the MENA countries, in terms of infrastructure investments and liberalization of the telecom markets, have affected network penetration, so it is crucial to explore the low level of fixed-line penetration witness in the MENA region compared with other, comparable regions.

Mobile services were introduced in the late 1990s, and their use has quickly expanded throughout the region. In most MENA markets, the market is oversaturated; 11 out of 17 countries have a mobile penetration rate of over $100 \%$. The average mobile penetration rate for MENA countries is $112 \%$, which is higher than all other rates in the LAC, EAP and OECD (104.7\%, 83.2\% and 106.6\%, respectively). In GCC countries, the increasing use of mobile services has been accompanied by a decrease in fixed-line penetration, which could explain the drop in fixed-line penetration rates. This situation is not the case for the other MENA countries, which initially suffered from reduced fixed-line penetration and where the boom in mobile services has been accompanied by an increase in fixed-line penetration.

To conclude, in comparisons with other regions (e.g., LAC and EAP), the MENA countries have the highest mobile penetration, although the evolution of fixed-line penetration is limited. Hence, what are

\footnotetext{
${ }^{9}$ The Gulf Cooperation Council "GCC" is composed of six countries; Bahrain, Kuwait, Oman, Qatar, Saudi Arabia and the United Arab Emirates. For instance, Bahrain, Kuwait, Qatar and the UAE have fixed-line penetration rates of over $20 \%$.
} 
the main reasons behind the limited evolution of fixed-line penetration for the MENA countries? Is the spectacular evolution in mobile penetration due to limited fixed performance?

After applying the different reforms on the group of MENA countries and exploring the unique evolution patterns for the MENA region's telecom performance, it is important to investigate the main reasons behind the low fixed-line penetration for MENA countries. Is the limited fixed-line penetration due to limited supply? Or is it due to excessive interconnection terms and high barriers to access the infrastructure set by the incumbent upon new entrants? Hence, it is important to test whether the telecom reforms adopted by MENA countries lessen those problems or if such reforms are just worsening MENA countries' telecom performance. In the context of the MENA countries, it is also worthy testing if such reforms are adapted to the economic, institutional and political characteristics of the MENA region.

\section{Related literature and testable hypotheses}

Our objective, in this section, is to analyze the relationship between the telecom reforms and the telecom performance for the MENA countries. Telecom reforms include regulation, privatization and liberalization, as well as their simultaneous presences, whereas telecom performance indicators include the three dimensions of access, affordability and productivity. In this section, we explore the existing literature to derive our testable hypotheses.

\subsection{Does the establishment of an IRA improve telecom performance?}

In the infrastructure industries, the importance of institutions, specifically for the developing countries, was mainly to address the underinvestment problem that occurs due to the sunk nature of the investments needed. Thus, having an independent regulator is considered to be a credible solution to alleviate the time inconsistency problem faced by investors (Trillas and Montoya 2011). The claim offered by politicians to justify the transfer of powers to a specific regulatory agency is that countries with independent regulators will achieve better policy outcomes than countries without independent regulators or that countries with more independent regulators will achieve better policy outcomes than countries with fewer independent regulators (Hanretty and Koop 2012). Although, in theory, other mechanisms could solve for the time inconsistency problem faced by regulators, the literature notes that it is difficult for developing countries to find credible alternative to an independent regulatory agency (Trillas and Montoya 2011).

The effect of the establishment of an independent regulator differs across empirical studies. Estache et al. (2006) use a sample of 204 countries to show that the introduction of an IRA helps to decrease the price of local calls and increase labor productivity. Surprisingly, the introduction of an IRA has no statistically significant impact on access or on the fixed component of the tariff paid by users. Ros (2003) finds that the existence of an independent regulator is positively associated with teledensity and operating efficiency in 20 Latin American countries. Gutiérrez (2003) constructs a regulatory independence index and finds that the higher the regulatory independence is, the higher the network deployment and telecommunications efficiency, when said model was applied to a sample of 22 Latin American countries. Others studies reach different results concerning the effect of the existence of an independent regulator. Wallsten (2003), using a large sample of 200 countries, finds that establishing an independent regulator is rarely and negatively significant and is correlated with the number of mainlines, mainlines per capita and investment, but it is correlated positively and significantly with the number of cellular subscribers. In their panel data analysis, Trillas and Montoya (2011) confirm that regulator independence is associated with higher network penetration, but the magnitude and statistical significance of this impact are low and difficult to assess.

It is quite clear that the impact of an independent regulator on the sector's performance is not consistent across the previous studies, which is mostly due to differences in the institutional, political and economic characteristics of the countries studied. Hence, to derive our first hypothesis, we rely on the theoretical role that the regulator should perform in order to be efficient. An independent regulator should ensure greater access for telecom users and higher sector productivity. However, an independent 
regulator may induce a price increase after the entry of new competitors and the elimination of crosssubsidization. Before the establishment of an IRA, retail tariffs were not rebalanced; however, after the introduction of the IRA, the regulator has to rebalance the tariffs, leading to an increase in prices.

Hypothesis 1. An independent regulator improves the sector's performance in terms of access and productivity, but it leads to price increases.

\subsection{Does ownership affect telecom performance?}

In spite of the importance of the state ownership to correct the market failure and to pursue nonprofitgenerating activities, a critical factor behind the privatization is the well-documented poor performance of public enterprises (Boycko et al. 1996). For the developing countries, the occurrence of privatization may be the expression of inefficient regulation, corruption or financial problems (Laffont 2005). In their article, Estache and Wren-Lewis (2009) state that, in the case of private ownership, this corruption will take the form of higher prices. For them, although international agencies advised countries to open their infrastructure industries to the private sector to increase their investments and improve their efficiency, privatization has been disappointing for countries with the lowest income. These failures were accompanied by increases in prices, which have led to large dissatisfaction with privatization.

In the literature, the effect of privatization on performance is not consistent across different studies. For Ros (1999), privatization can have positive effects because managers will capture the benefits (either cost savings or profits) resulting from privatization. Thus, it increases managers' incentives to reduce costs and to increase productivity. From another side, the privatization can have drawbacks. Privatized firms can increase their profitability by restricting output or by restricting nonprofit objectives as provision of universal service ( $\mathrm{Li}$ and $\mathrm{Xu}$ 2004). Consequently, the existence of a regulator is important to deter privatized firms from such practices. Furthermore, the risk that the government may opportunistically decide to enforce low prices, without allowing the firm to recover the costs induced by large sunk investments, gives rise to the problem of underinvestment (Vickers and Yarrow 1991). Thus, the impact of privatizing the incumbent operator highly depends on the existence of an independent regulator. In Wallsten (2001), the privatization alone is associated with few benefits and is negatively correlated with mainline penetration and connection capacity. When it is combined with an independent regulator, it is positively correlated with telecom performance measures. So, the simultaneous presence of an IRA and a private incumbent helps to mitigate the negative effects of privatization on mainline penetration.

Moreover, private ownership becomes more efficient when there is effective competition (Gual and Trillas 2006). For Estache and Wren-Lewis (2009), the private ownership has not improved performance, notably in sectors where there is no competition. Empirically, Fink et al. (2001), in the context of 12 developing Asian economies over the period 1985-1999, show that privatization alone may not lead to great strides if the privatized monopoly is not exposed to competition. We also expect that, when a privatized monopoly is exposed to competition, this will mitigate the negative effects that could arise from privatizing the incumbent.

\section{Hypothesis 2.}

2.a. Privatization leads to higher prices and lower access.

2.b. The presence of an independent regulator and a private incumbent simultaneously improves telecom performance.

2.c. When a privatized incumbent is exposed to competition, this helps to improve telecom performance.

\subsection{How does competition improve telecom performance?}

It is well known that competition between firms brings improvements in terms of allocative efficiency, as well as internal (technical) efficiency. Moreover, competition is crucial because it helps to avoid the problem of limited regulator capacity and serves as a pressure on the firm to keep prices low (Estache and Wren-Lewis 2009). Therefore, there is a general consensus that competition in the non-natural monopoly segments of telecommunications is beneficial for welfare through improvements in incentives 
and productivity (Gual and Trillas 2006). In the following, we focus on service-based competition, rather than facility-based competition.

Because the incumbents have the largest sunk investments in the infrastructure and are the main infrastructure providers for new entrants, they have a competitive advantage that can be exploited against them. To promote service-based competition, the regulator should guarantee access to the incumbent network by new entrants. As a result, interconnection agreements are a critical factor for making the competition viable in the market. An incumbent operator has no incentive to establish suitable interconnection terms to promote competition in the market in which it is a monopoly. So, the effect of competition on network expansion depends on whether the interconnection terms are suitable for promoting the entry of new competitors in the market or if they are in favor of the incumbent operator, thereby being considered barriers to entry and leading to entry deterrence. We should then avoid any anticompetitive behavior by the incumbent such as setting excessive interconnection rates, refusing to make available adequate interconnection capacity or refusing to share its network.

Here arises the importance of the regulator. To ensure effective competition in the market, the regulator should pave the way for effective market liberalization. Given the nature of the telecom sector, the existence of a regulator is important to prevent anticompetitive practices; by ensuring that the interconnection terms are well established, consumers have lower prices and investors have profits. Laffont (1998) argued that liberalization can proceed safely only to the extent that strong regulatory institutions are established. Accordingly, it is crucial to have an independent regulator when introducing competition. Even if competition is introduced, the regulator should reduce market power and set access prices. As explained by Estache and Wren-Lewis (2009), the experience in developing countries suggests that the regulation of partially competitive sectors can be as demanding on regulators as monopoly regulation. However, the regulatory capture by the incumbent should be avoided, because regulators are sometimes reluctant to introduce competition given that it has been considered an approach that destroys their rents from the historical operator. Finally, competition kills cross-subsidies (Laffont 1998); for this reason, the effect of competition on prices may be surprising. Laffont (1998) suggests a partial reintegration of cross-subsidies in developing countries that is not incompatible with introducing competition.

To derive our hypothesis on the effect of competition, we assume that the regulator is effective. In other words, we assume that the incumbent operator doesn't abuse its dominant position, the interconnection agreements are not excessive and regulatory capture is prevented, i.e., assuming that competition would improve the sector's performance in terms of access, productivity and affordability.

\section{Hypothesis 3.}

3.a. Competition leads to higher penetration and productivity, as well as to lower prices.

3.b. The simultaneous presence of an independent regulator and introducing competition would lead to better sector performance.

\subsection{Do institutional, economic and political factors affect telecom reforms?}

Levy and Spiller (1994) draw attention to the impact of political and social institutions on the type of regulation that can be implemented. The authors show that the credibility and effectiveness of a regulatory framework and its ability to facilitate private investment vary with the country's political and social institutions. Thus, privatization in countries that lack the formal and informal institutions will require the development of alternative safeguards; thus, investors will not be reluctant to invest. In this subsection, we argue that institutional, economic and political factors explain the reforms adoption by the MENA countries. According to Ros (1999), the regulatory framework, affected by political and social institutions, determines in part the success or failure of privatization.

First, we argue that the adoption of reforms is affected by the level of democracy established in each country. So, the intensity of the democracy indicator would affect different reforms adopted by the MENA countries, such as the establishment of an IRA, the attractiveness of private investments and market openness for potential entrants. According to Giuliano et al. (2012), democracy has a positive and significant impact on the adoption of economic reforms, but there is no evidence that economic 
reforms will foster democracy. Theoretically, the economic theory does not give clear answer on whether democracy favors or hinders the economic reforms or if the relationship could go both ways (Giuliano et al. 2012). Empirically, only a few papers study the relationship between democracy and reforms. Giavazzi and Tabellini (2005) study the relationship between democracy and trade reform on 140 countries from 1960 to 2000, and they find a positive relationship between democracy and trade reform. Similarly, Djankov and Amin (2009) findings confirm that an expansion of democratic rights encourages micro-economic reform from the World Bank's Doing Business database and is likely to increase efficiency and growth. Quinn (2000) studies the relationship between international finance regulation and democracy and finds that democracies liberalize international finance. The level of democracy appears to be a valid instrument for telecom reforms because it can be treated as exogenous to our outcome variables; overall democracy is not likely to have a direct effect on telecom market performance other than through the adoption of reforms. Moreover, telecom reforms are sufficiently micro-measured; in this way, it is not possible that they would alter the level of democracy.

Legal origins, our second determinant for reforms adoption, were introduced in many countries through colonization. As discussed in a study by La Porta et al. (2008), the legal origin of a country is considered to be a style of social control of economic life, and such styles have developed, survived over the years and continued to have substantial economic consequences. Such styles prove its persistency in different countries and are very difficult to be altered. Furthermore, the historic origin of a country's laws is highly correlated with a broad range of its legal rules and regulations, as well as with economic outcomes (La Porta et al. 2008). Gual and Trillas (2006) consider the legal origin of each country to reflect its interventionist tradition and the degree to which the state has an inclination to intervene in economic matters. The effect of legal origin has been tested on different dimensions in the literature, among them financial development (La Porta et al. 2006), the government ownership of banks (La Porta et al. 2002), the government ownership of the media (Djankov et al. 2001) and the government ownership of labor markets (Botero et al. 2004). With a focus on the effect of legal origins on government regulation, La Porta et al. (2008) found that - for a broad range of activities - civil law countries are characterized by government ownerships, whereas common law countries are more likely to use private contracts. The authors conclude that common law countries have better investor protection, lighter government ownership and regulation, and more independent judicial systems, which are associated with more secure property rights. To summarize, legal rules protecting investors vary systemically among legal origins, with common law countries being more protective of outside investors than civil law countries. We argue, then, that the historic legal origin of each country affects a reform's adoption - specifically, the incumbent privatization and the market liberalization. Legal origins seem to be a valid instrument for telecom reforms because they are considered to be historic facts that are difficult to be altered. Obviously, telecom market performance could not shape the legal origins of each country; for these reasons, they are considered to be exogenous to telecom market reforms.

Another set of factors that would affect the reform adoption include natural resources; as an important source of rents for some MENA countries. Most MENA countries are known by their abundant natural resources, including oil, natural gas, coal, mineral resources and forests. According to the World Development Indicators (2013), the Arab World and MENA countries lead the world in natural resources rents. In fact, the motive for public ownership of incumbent operators has been that the government desires to keep control on the rents produced to exploit oil and other non-renewable natural resources (Goldstein 2002). Moreover, as already mentioned, major reforms are introduced under the pressures of the IMF and the WB in order to reschedule debt service payments or resort for new loans. Countries, independent in their resources, are then less forced to adopt reforms under such pressures.

Finally, we need to control for the year of independence from colonization for each country, which is also considered to be a historic factor that would affect the lags in the establishment of an independent regulator. Thus, the latter is the independence year, with reduced time available for the country to develop its national requisite institutions and rid itself of pre-independence institutions.

To sum up, it would be interesting to test the interplay between institutional, economic and political determinants and the adoption of telecom reforms to explain different factors leading to reform adoption. 


\section{Hypothesis 4.}

4.a. A more democratic country is more likely to adopt telecom reforms.

4.b. A country with a civil law origin is less likely to adopt reforms - specifically, the incumbent privatization and the market liberalization.

4.c. Countries are more reluctant to adopt different reforms when they have abundant natural resources.

4.d. Latter is the independence year from colonization, more are the lags in reforms adoption.

\section{Empirical strategy}

\subsection{Instrumental variable estimation}

To test the effect of reforms on telecom performance, we estimate the following model by using IV2SLS estimation procedure (Instrumental Variable-Two Stages Least Squares estimation) ${ }^{10}$ while accounting for the endogeneity of reforms and while including year dummies ${ }^{11}$. We adopt a log-linear specification to transform different variables into a normal distribution. The regression takes the form:

$$
\mathbf{Y}_{i t}=\beta_{0}+\beta_{1} R_{i t}+\beta_{2} X_{i t}+Z_{t}+\mu_{i t}
$$

Where $\boldsymbol{Y}_{\boldsymbol{i t}}$ is one of the three performance indicators we have chosen to consider, $\boldsymbol{R}_{\boldsymbol{i t}}$ is a vector of reform variables and their interactions, $\boldsymbol{X}_{\boldsymbol{i t}}$ is a vector of control variables (GDP per capita and population density), $\boldsymbol{Z}_{\boldsymbol{t}}$ are year dummies and $\boldsymbol{\mu}_{\boldsymbol{i t}}$ is the disturbance term. An equation is estimated for each of the dependent variables we consider here.

It is obvious that the reform variables are endogenous, which means that they can affect one another and are also affected by different levels of performance. Typically, a low level of performance would be a motive for the government to establish an independent regulator in order to increase the sector's performance. Moreover, the actual level of demand, productivity and prices would shape the decision of new entrants to operate in the market. Additionally, the existence of an independent regulator in the market may be an important determinant for new investors, to serve as a guarantee that they would have profits in the long run and that they would not be harmed by anticompetitive behaviors. Furthermore, if the private investors are very interested in the performance indicators before going through the privatization process, the government may increase the efficiency of the incumbent operators in order to attract investors when introducing privatization (Gasmi et al. 2013).

To get the first stage results, we test the effect of the institutional, economic and political variables, used as instruments, on different reforms variables. Specifically, we model the decision to establish an independent regulator, privatize and foster competition, using an OLS model. The regressors principally respond to the democracy indicator, the legal origin, the natural resources rents as a \% of GDP and the independence year from colonization, plus the exogenous variable we use in the second stage equation (such as population density, GDP per capita and year dummies).

\subsection{Data $^{12}$}

The previous hypotheses, mentioned in section (3), will be tested using a panel dataset of the 17 MENA countries from 1995 to 2010 . We construct our original database from various sources, as detailed in this section. Moreover, we are focusing only on the voice market for the fixed and mobile segments ${ }^{13}$.

\footnotetext{
${ }^{10}$ Even if our endogenous variables are discrete variables, the consistency of IV-2SLS does not require the endogenous variables to be continuous (Heckman and Robb 1985). Using the logit model in the first stage is unnecessary, because in 2SLS estimation, the consistency of the estimates in the second stage is not dependent on the correct functional form in the first stage. Moreover, performing the 2SLS's step-bystep procedure leads to inconsistent standard errors because it does not take into account, in the second stage, that the endogenous variables were predicted in a previous step.

${ }^{11}$ We do not use fixed-effects estimation. Because that approach does not allow for the estimation of time-invariant effects, such variables are dropped from the estimation process. In our sample, we have some time-invariant variables whose effects would be lost in the fixed-effects estimation. Fixed effects methods are useless for estimating the effects of variables that do not change over time. Fixed effects and firstdifferencing methods can lead to imprecise estimates in cases where the key variables in $\mathrm{X}_{\mathrm{t}}$ do not vary much over time (Wooldridge 2010 ).

${ }^{12}$ See Table 3 for the variables list and Table 4 for the summary statistics.

${ }^{13}$ The data services market is outside the scope of this paper.
} 
To assess the performance, we use three different dimensions: access rates, productivity and affordability of services, as used by Estache et al. (2006). We use different proxy variables to reflect those dimensions. To reflect access rates, we use as dependent variables fixed and mobile penetration (the number of fixed and mobile telephone lines in a country per 100 inhabitants, transformed by the natural $\log ) .{ }^{14}$ Productivity is measured by the number of telephone subscribers in fixed and mobile telephone per employee (employed by total full-time telecommunication employee) ${ }^{15}$. To measure affordability, we use prices indicators ${ }^{16}$ as the monthly subscription for residential telephone service in US\$ as in Estache et al. (2006) and Gasmi et al. (2013), and the price of a 3-minute fixed telephone local call (off-peak rate) in US\$ as was used by Wallsten (2001), Li and Xu (2004) and Estache et al. (2006). We also use mobile price of 3-minute local call (off-peak) in US\$ to reflect mobile affordability as in Gasmi et al. (2013), but at the peak rate. Thus, the data we use are the best data available to date. The data on the performance indicators come from the ITU database.

To measure the effect of regulation, we use a dummy variable that equals 1 if an independent regulatory authority exists in a country in a specific year. The creation of an IRA per country is documented in the ITU World Telecommunication Regulatory Reports 2012, "Does a separate Regulatory Authority exist for Telecommunication or Information and Communication Technology (ICT) in your country?"17 This measure doesn't reflect the degree of independence, but it is the only measure available we can rely on due to the lack of detailed information on the regulatory functions for a long period of time ${ }^{18}$. As a consequence, interpreting its effect in a regression is related to attempts at regulatory reform rather than the effect of being an independent entity (Wallsten 2001). We collect data for regulation from the ITU database and different regulators' websites. Another dummy variable is constructed for privatization ${ }^{19}$. This variable takes the value of 1 starting from the year when any part of the fixed incumbent operator was privatized. If it is only transformed into a Joint Stock company, this does not imply its privatization because, in most the cases in the MENA countries, it remains a stateowned company. The data are collected from the ITU website, incumbent operators' websites and the Ministries of Communications websites in each country. To measure the effect of competition, we collect data on the number of fixed operators, as well as the number of mobile operators per country. Those numbers are based on the date in which the company started operating in the market, which is more reliable and reflects effective competition rather than the existence of licenses in a particular segment. We construct dummy variables for the competition in the fixed and the mobile segment. Then, to reflect the state of competition in the telecom market, we construct an index as in $\mathrm{Li}$ and $\mathrm{Xu}$ (2004); this index is constructed as follows: it equals 0 if a monopoly exists in both segments (fixed and mobile), it equals 1 if at least one segment operates with more than one operator, and it equals 2 if both segments become competitive. Data for competition come from the ITU website, different regulators and operators' websites and the Ministries of Communications websites per country.

To test the effect of the simultaneous presences of different reforms, we use three interaction variables to introduce different reform interactions ${ }^{20}$ : regulation-privatization, privatization-fixed competition and competition-regulation. Then, we construct a three-way interaction variable ${ }^{21}$, regulation-privatization-competition. It is the product of the three reforms dummies, so it takes the values 0,1 or 2 .

\footnotetext{
${ }^{14}$ This measure is used by different authors (Ros 1999; Ros 2003; Fink et al. 2001; Fink et al. 2003; Wallsten 2001; Li and Xu 2004; Gual and Trillas 2006; Gasmi et al. 2013; Trillas and Montoya 2011).

${ }^{15}$ This measure is used in different studies (Ros 1999; Ros 2003; Gutiérrez 2003; Li and Xu 2004; Gual and Trillas 2006; Gasmi et al. 2013). We use this method to measure productivity, because we do not have the number of telecom employees per segment. We find that dividing the number of mainlines by the number of staff employed by telecom operators is not reliable, as used in (Ros 1999; Ros 2003; Fink et al. 2001; Fink et al. 2003; Wallsten 2001; Li and Xu 2004; Gual and Trillas 2006; Gasmi et al. 2013; Trillas and Montoya 2011 ).

${ }^{16}$ Given by the ITU Database (2011).

${ }^{17}$ In this survey, ITU defines separate as "independent" in terms of finance, structure, and decision making from the operator(s) and the sector's Ministry.

${ }^{18}$ We prefer to construct an index to reflect regulatory powers and functions, but limited published information for the whole period prevent us from doing so because we have only one year per country data. As stated by Wallsten (2001), "Acquiring such information-especially for developing countries - is a Herculean task". We will correct for this limitation by having a two-stage estimation procedure.

${ }^{19}$ We use a dummy variable due to the lack of data on the percentage of privatization of the incumbent operator.

${ }^{20}$ Working with 86 developing countries, Fink et al. (2003) test the effect of the existence of an independent regulatory authority only when combined with other reforms. They find that complete liberalization pays off and positively affects teledensity and labor productivity.

${ }^{21}$ Fink et al. (2001) find a positive contribution of liberal policy (measured by a three-way interaction term) to the performance of telecommunication services in 12 developing countries in Asia.
} 
In our model, we control for demographic and macroeconomic variables, such as GDP per capita as a determinant of demand and population density as a determinant of the market size. These data come from the World Development Indicators "WDI" database, as provided by the World Bank. Additionally, we include year dummies to measure time fixed-effects.

Finally, to correct for the possible endogeneity of reforms variables, first, we use the Polity IV Project's political regime indicator for democracy as a political variable. It ranges from -10, fully institutionalized autocracy, to +10 , fully institutionalized democracy. These data are available at the Center for Systemic Peace Web site "Polity IV". Then, we normalize the variable to be in the range from 0 to 1 . Then, to take into account the legal origin for each country (either civil law or common law), we collect data from the CIA World Factbook on the legal origin. We construct a dummy variable that equals 1 if the country has a civil legal origin, and zero otherwise. Moreover, we use the total natural resources rents (\% of GDP) to reflect the country's natural resources potentially leading to rents. These data come from the WDI database created by the World Bank. Finally, we collect data about the year of independence from colonization for each MENA country from the CIA World Factbook data.

\subsection{Results $^{22}$ and robustness checks}

\subsubsection{First-stage estimation findings ${ }^{23}$}

In our first-stage regression in Table 8, most of our results are in line with the theory (hypothesis 4); only hypothesis (4.a) is not validated. For the democracy effect on the adoption of reforms, our results show the absence of a relationship between democracy and the establishment of an independent regulator and a negative relationship between democracy and the other reforms (in terms of the privatization process and the introduction of competition). This result reflects the fact that democracy is not well established in MENA countries. In other words, depending on the political nature of a particular MENA country, it may not benefit from the otherwise positive impacts of establishing a democracy. Additionally, as noted by La Porta et al. (2008), we find that a civil law country is less likely to adopt telecom reforms specifically-i.e., adopt the privatization process and the introduction of competition - than is a common law country. This result confirms the fact that civil law countries are subject to government ownership, whereas common law countries are more likely to use private contracts. Moreover, we find that, when the country is somehow independent in its resources (i.e., high in natural resources rents as percentage of GDP), it is not compelled or forced to adopt different reforms under IMF and WB recommendations. Finally, the later the country achieved its independence from colonization was, the more it is delayed in establishing an independent regulatory institution, which implies greater delays in the adoption of reforms, thus describing a long-term negative impact of colonization on the adoption of reforms.

\subsubsection{IV-2SLS estimation findings}

Table 9 shows the estimations for the regressions of different performance indicators on our three reform-related variables. We also estimate the effect of competition on the fixed-line market, as well as on the mobile market separately. ${ }^{24}$ The results show that establishing an independent regulator has a positive effect on telecom access and that it helps to increase telecom productivity. Moreover, it leads to a price increase in the fixed sector measured by the residential monthly subscription. Such an increase can be explained by the tariff rebalancing system ${ }^{25}$ and the elimination of cross-subsidization. Hence, our results on the effect of the establishment of an independent regulator on the sector's performance

\footnotetext{
${ }^{22}$ See Table 5 and Table 6 for the OLS fixed-effects estimations.

${ }^{23}$ To ensure the validity of our instruments, we test the effect of each IV, as well as the control variables and the year dummies, on each performance indicator to confirm that our institutional and political variables are not directly correlated with the performance indicators. See Table 7 for the estimations. We find that they have an insignificant effect on our different performance indicators, except the year of independence, which affects fixed-line penetration negatively.

${ }^{24}$ We estimate the separate effect to avoid having more than one endogenous variable in the same equation.

${ }^{25}$ Tariff rebalancing seeks to increase access prices and reduce prices for services that have traditionally subsidized low access prices. The objective is to ensure that the price for each service reflects the underlying cost of providing that service. It typically takes place when ending direct subsidies as part of most reforms.
} 
confirms hypothesis (1). Then, we find that the privatization has a negative significant effect on fixed access; however, it has a positive effect on the productivity measure. Privatization increases fixed prices in terms of the monthly residential subscription and the 3-minute fixed call, which validates our hypothesis (2.a). The third reform variable, competition, leads to lower access and higher prices in the fixed segment. However, in the mobile segment, competition helps to reduce prices, with no effect on mobile access. Moreover, competition has no effect on the productivity measures for either sector. The results related to the competition variable fail to confirm our hypothesis (3.a).

Table 10 shows the interaction results of the reforms (i.e., regulation-privatization, fixed competition-privatization, regulation-competition and, finally, their three-way interaction). When we take the interaction terms into consideration in the regression, this affects our performance indicators. For instance, when an independent regulator and a private incumbent exist simultaneously, this helps to improve the sector's performance by eliminating the negative effect of privatization on fixed access. Although privatization increases prices in terms of fixed residential subscriptions-which ensures the tariff rebalancing system - such an increase is so large that it can be attenuated when there is a regulator in place. However, an independent regulator eliminates the negative effect of a privatized incumbent on the 3-minute fixed call and induces a price increase. This negative effect on prices may be considered predatory pricing, which deters other entrants from operating in the market. However, such behavior is avoided by the independent regulator. These effects confirm our hypothesis (2.b).

When we take into consideration the interaction between the incumbent's privatization and fixed competition, we find that this interaction has no significant effects on most of the performance indicators. This interaction has a positive effect only on fixed affordability; this implies that the effective fixed competition does not help to reduce the negative effect of privatization on access and affordability. Thus, hypothesis (2.c) is not validated.

Finally, the simultaneous presence of an independent regulator and the introduction of competition has no effect on telecom access. However, it has a negative effect on productivity; the independent regulator's effect on productivity is reduced the more competitive the market becomes. This phenomenon can be due to some regulatory constraints on the new entrants or due to the need to improve regulatory efficiency in the market in terms of setting suitable interconnection terms, adopting greater transparency in the licensing process and avoiding regulatory capture by the incumbent operator. When we test the partial effect of competition on fixed prices, we find that - within a competitive telecom market - an IRA would eliminate the negative effect of competition on residential prices and turn it into a small positive effect due to the tariff rebalancing system. However, an IRA does not eliminate the negative effect of competition on the 3-minute fixed prices, although it does reduce that effect. This phenomenon may attenuate large decreases in prices that would be considered anticompetitive behaviors. These results do not validate our hypothesis (3.b).

When we take into account the three-way interaction between the three reform variables - the establishment of an independent regulator, the privatization of the incumbent operator and the introduction of competition - we find that the simultaneous implementation of the three reforms helps to increase mobile access and telecom productivity. However, a negative effect on the fixed access remains. Additionally, this interaction has a positive effect on fixed prices, which means that, in the end, it is also important to offer incentives to foreign investors and new entrants to operate in the market with high - but not excessive - prices, to allow high profits. However, this interaction has no effect on mobile prices, which are determined by market forces in almost all countries.

\subsubsection{Robustness Checks}

To ensure the robustness of our results, we take into consideration the fact that different telecom reforms in year $\mathrm{T}$ would affect different telecom performance indicators at year $\mathrm{T}+1$ instead of year $\mathrm{T}$. So, we test the effect of different reforms, as well as their interactions, at year $\mathrm{T}$ on different performance indicators at year $\mathrm{T}+1$, using IV-2SLS estimation (see Table 11 and Table 12). The results for different telecom reforms, as well as for their different interactions, are totally robust, although they sometimes show different levels of significance. Moreover, our models are also robust in terms of magnitude and coefficients for the inclusion of the time trend instead of the year dummies, except for the competition effect on telecom performance (i.e., its effect on telecom access is no long significant); 
however, it is still robust for the separate effects of fixed competition and mobile competition. Finally, we test the effects of the various reforms simultaneously in the same equation, and we find that the coefficients are still robust in terms of significance but with different magnitudes, although this robustness does not apply to the competition variable.

\section{Discussion}

The results on the impact of an IRA on the sector's performance in the MENA region should be considered carefully because the IRA dummy variable does not measure the extent of regulatory independence even if it has claimed to be independent according to ITU reports. In general, the existence of an independent regulator is only efficient when it has powers, credibility and competences (Spiller 1993; Gilardi 2005; Hanretty and Koop 2012). Thus, the regulator has to be given all the conditions necessary to work effectively, in a way that guarantees its transparency and accountability. Despite the positive effects of the independent regulator on the different performance indicators when its effect is tested separately, the simultaneous presence of an IRA and market liberalization is found to be inefficient when taking into account the institutional and political contexts of the MENA countries. In other words, an IRA is not efficient at achieving telecom market liberalization. In other terms, new entrants may have no incentives to operate in the market. Hence, an IRA should be more effective by setting suitable interconnection terms, avoiding regulatory capture by the incumbent that would prevent competitors from entering the market, guaranteeing more transparency in the licensing process and ensuring that the incumbent would share its network with new market entrants. Thus, the establishment of an independent regulator is a necessary condition to improve sector performance rather than a sufficient condition for effective regulation.

An incumbent's privatization has many controversial implications on the sector's performance in our regressions. The negative relationship between privatization and fixed-line penetration could be explained as a reverse-causation problem; when fixed-line penetration is very low, the marginal utility of privatizing the incumbent operator increases, which encourages governments to privatize. Additionally, investors may decide not to increase the number of subscribers unless it is profitable for them. This implies that a privatized firm - specifically, a privatized monopoly - is able to increase its profitability by restricting output. Specifically, in the context of developing countries, there is a large need to invest in infrastructure, which would not be profitable for investors in the short term. So, this negative effect may be the result of ineffective regulation with no incentives to invest. Additionally, the positive effect of privatization on residential fixed prices implies that transforming a state-owned operator to a private one may not be constructive if it remains a monopolist. This may be due to the inefficiency of the regulator; hence we study the effect of privatization combined with an IRA.

Concerning market liberalization, competition in the mobile segment improves the sector's performance by decreasing mobile prices. However, the same is not the case for the fixed segment; having a competitive fixed-line market leads to lower access and higher prices, which may be due to the effect of tariff rebalancing. As a consequence, actual competitive reforms are not enough to improve the fixed sector's performance.

Obviously, the privatization of an incumbent operator combined with an IRA is important because, theoretically, a privatized incumbent can abuse its position by restricting output, by excessively increasing prices (specifically, the fixed monthly subscription) or by setting predatory prices, which requires regulatory intervention. Moreover, without an IRA, no privatized incumbent operator would allow competition because it would not be profitable for it, specifically when there is no competition authority that would oversee the incumbent behavior and induce competition in the market. ${ }^{26}$ Accordingly, the simultaneous presence of an independent regulator and a private incumbent is not fully sufficient to eliminate the negative effects attached to privatization; however, such a simultaneous occurrence is necessary and needs to be more efficient. This result reflects the importance of institutions' setting market rules, because a privatized incumbent can abuse its dominant position, which

\footnotetext{
${ }^{26}$ The MENA competition authorities are not yet fully established. The MENA countries that have competition laws include Jordan, Lebanon, Oman, Saudi Arabia, Algeria, Egypt, Morocco, and Tunisia. The countries that do not have competition authorities include Syria, Yemen, and Libya.
} 
would have negative effects on new entrants, as well as on consumers. However, the results of the simultaneous presence of fixed competition and the privatization of the incumbent operator are very astonishing. Although the existence of other competitors in the market is considered a guarantee for consumers, the existence of competition does not eliminate the drawbacks of privatization. Therefore, more fixed competition is crucially needed in the fixed segment in the MENA region, while simultaneously improving the efficiency of the regulator in monitoring the market. In this way, the privatized incumbent could operate efficiently in the market in the presence of other competitors.

The insignificant effect of the simultaneous presence of an IRA and market liberalization on fixed and mobile access implies that the regulator is not efficient for promoting competition in the market and that more rules are needed to guarantee its efficiency by setting suitable interconnection rules and by avoiding regulatory capture by the incumbent operator. An IRA's stimulation of market liberalization is very crucial. First, an IRA has to encourage entry by ensuring that new entrants would be able to provide telecom services by accessing the incumbent's networks through "third-party access" and then by assuring that they would earn profits. Second, it should make competition effective by lowering consumer prices. Hence, its role is crucial to ensure that operators and consumers are not adversely affected by liberalization.

Last, having the three reforms occur simultaneously is not enough to eliminate the negative effect on the fixed sector's penetration, although it has a positive effect on the mobile sector's penetration. The remaining negative effect on the fixed sector's penetration requires more explanation: the persistence of economies of scale in the fixed segment is considered to be a barrier that prevents competitors from competing in the facility-based market. On that account, having more firms operating in the servicebased market would require access to the incumbent's fixed networks, which clearly requires suitable interconnection agreements. Thus, such negative effects can occur because governments are not paving the way for successful service-based competition. These negative effects may be due to unreasonable interconnection terms that prevent competitors from operating in the market, to the use of existing networks or to the need for a high level of investment in the fixed segment, such that many competitors could operate on the same network. In terms of institutional explanations, this negative effect can be due to regulatory capture by the incumbent operator. Moreover, the type of regulations in place matter; if the fixed segment is more regulated than the mobile segment, then once the incumbent operator is privatized, the investor will switch to the less-regulated and less-infrastructured segment, which would be more profitable for him.

The previous results are of great importance to policymakers for adopting policies that suit the telecom market in MENA countries. For instance, policymakers could increase the level of competition in the fixed-line market without the need for a high level of investment by leasing the incumbent's network. For instance, in Morocco, the incumbent has leased its network to new market entrants since 2007. Another way to increase competition on the service-based level is by unbundling the incumbent's network, as was the case in Bahrain. Although local loop unbundling becomes standard in most developed countries, its effect is not guaranteed for the MENA countries. However, testing the unbundling effect empirically for the MENA region is difficult due to the lack of data.

\section{Conclusion}

Overall, this paper is a first attempt to test the effect of telecom reforms on sector performance in the MENA region. The telecom reforms in the MENA countries, in terms of the establishment of an independent regulator, privatization and liberalization, have been much slower than in other regions. To account for the possible endogeneity of telecom reforms, we use IV-2SLS estimation by assuming that different reforms are affected by institutional, political and economic determinants. We find that the MENA countries truly suffer from the lack of independent regulatory institutions; this issue has greater implications for the fixed rather than the mobile market. Therefore, the main concern of policymakers should be the guarantee of an efficient and truly independent regulator.

Moreover, the effects of telecom reforms and their simultaneous implementation with regard to fixed access should be the focus of attention for policymakers. New rules should be put in place to ensure an effective telecom market, effective competition in the fixed segment and better monitoring of 
newly privatized incumbents. Moreover, a regulator should guarantee the competitors' access to the incumbent's networks at reasonable terms, because the incumbent operator is controlling the fixed infrastructure. This guarantee is important to ensure the competition's viability in the service-based market for the fixed and the mobile segments.

An interesting issue that needs to be addressed in further studies is the sequence with which the reforms are introduced in the telecom market for MENA countries. Does the prior existence of an independent regulator before the incumbent's privatization and before the market's liberalization matter for the telecom sector's performance? Does an IRA represent a guarantee for new investors and entrants that would encourage them to enter the market?

\section{References}

Bortolotti, B., D’Souza, J., Fantini, M., \& Megginson, W. L. (2002). Privatization and the sources of performance improvement in the global telecommunications industry. Telecommunications Policy, 26(5), 243-268.

Bortolotti, B., Fantini, M., \& Siniscalco, D. (2004). Privatisation around the world: evidence from panel data. Journal of Public Economics, 88(1), 305-332.

Botero, J. C., Djankov, S., La Porta, R., López de Silanes, F., \& Shleifer, A. (2004). The regulation of labor. The Quarterly Journal of Economics, 119 (4), 1339-82.

Boycko, M., Shleifer, A., \& Vishny, R. W. (1996). A theory of privatisation. The Economic Journal, 309-319.

Boylaud, O., \& Nicoletti, G. (2000). Regulation, market structure and performance in telecommunications. OECD Economics Department Working Papers (Vol. 237). Paris: OECD.

Cambini, C., \& Franzi, D. (2013). Independent regulatory agencies and rules harmonization for the electricity sector and renewables in the Mediterranean region. Energy Policy, 60, 179-191.

Cambini, C., \& Jiang, Y. (2009). Broadband investment and regulation: A literature review. Telecommunications Policy, 33(10), 559-574.

Cambini, C., \& Rubino, A. (Eds.). (2014). Regional Energy Initiatives: MedReg and the Energy Community. Routledge.

Djankov, S., \& Amin, M. (2009). Democracy and Reforms. World Bank Policy Research Working Paper Series, 4835. Washington, DC: The World Bank.

Djankov, S., McLiesh, C., Nenova, T., \& Shleifer, A. (2001). Who owns the media? (No. w8288). National Bureau of Economic Research. Rochester, NY: Social Science Research Network.

Estache, A., Goicoechea, A., \& Manacorda, M. (2006). Telecommunications performance, reforms, and governance. World Bank Policy Research Working Paper, 3822. Washington, DC:The World Bank.

Estache, A., \& Wren-Lewis, L. (2009). Toward a theory of regulation for developing countries: following Jean-Jacques Laffont's lead. Journal of Economic Literature, 729-770.

Fink, C., Mattoo, A., \& Rathindran, R. (2001). Liberalizing basic telecommunications: The Asian experience. World Bank Policy Research Working Paper No. 2718. Washington, DC: World Bank.

(2003). An Assessment of Telecommunications Reform in Developing Countries. Information Economics and Policy, 15 (4), 443-66.

Gasmi, F., Maingard, A., Noumba, P., \& Recuero Virto, L. (2013). The Privatization of the Fixed-Line Telecommunications Operator in OECD, Latin America, Asia, and Africa: One Size Does Not Fit All. World Development, 45, 189-208.

Giavazzi, F., \& Tabellini, G. (2005). Economic and political liberalizations. Journal of Monetary Economics, 52(7), 1297-1330. 
Gilardi, F. (2005). The institutional foundations of regulatory capitalism: the diffusion of independent regulatory agencies in Western Europe. The Annals of the American Academy of Political and Social Science, 598(1), 84-101.

Giuliano, P., Mishra, P., \& Spilimbergo, A. (2012). Democracy and reforms: evidence from a new dataset (No. w18117). National Bureau of Economic Research.

Goldstein, A. (2002). Institutional endowment and regulatory reform in telecoms: a five-country comparison in the MEDA region. Mimeo, OECD Development Centre, Paris.

Gual, J., \& Trillas, F. (2006). Telecommunications policies: measurement and determinants. Review of Network Economics, 5(2).

Gutiérrez, L. H. (2003). The effect of endogenous regulation on telecommunications expansion and efficiency in Latin America. Journal of regulatory economics, 23(3), 257-286.

Hanretty, C., \& Koop, C. (2012). Measuring the formal independence of regulatory agencies. Journal of European Public Policy, 19(2), 198-216.

Heckman, J. J., \& Robb Jr, R. (1985). Alternative methods for evaluating the impact of interventions: An overview. Journal of Econometrics, 30(1), 239-267.

ITU. (2013). World Telecommunication/ICT Indicators Database for 2011. http://www.itu.int/opb/publications.aspx?media=electronic\&parent=D-IND-WTID.OL-2011. Accessed October 2012.

ITU. (2013). ITU World Telecommunication Regulatory Reports 2012. http://www.itu.int/net4/itud/icteye/FocusAreas.aspx?paramWorkArea=TREG. Accessed October 2012.

Joskow, P. L. (2007). Regulation of natural monopoly. Handbook of law and economics, 2, 1227-1348.

Karshenas, M. (1994). Structural adjustment and employment in the Middle East and North Africa. In Economic Research Forum Working Papers (No. 9420).

La Porta, R., Lopez-de-Silanes, F., \& Shleifer, A. (2002). Government ownership of banks. The Journal of Finance, 57(1), 265-301.

La Porta, R., Lopez-de-Silanes, F., \& Shleifer, A. (2006). What works in securities laws?. The Journal of Finance, 61(1), 1-32.

La Porta, R., Lopez-de-Silanes, F., \& Shleifer, A. (2008). The economic consequences of legal origins. Journal of Economic Literature, 46(2), 285-332.

Laffont, J. J. (1998). Competition, Information and Development. World Bank. (2005). Regulation and Development. Cambridge University Press.

Levy, B., \& Spiller, P. T. (1994). Institutional Foundations of Regulatory Commitment: A Comparative Analysis of Five Country Studies of Telecommunications Regulation. Journal of Law, Economics and Organization, 10(2), 201-46.

(1996). Regulations, Institutions, and Commitment: Comparative Studies of Telecommunications. Cambridge University Press.

Li, W., \& Xu, L. C. (2004). The impact of privatization and competition in the telecommunications sector around the world. Journal of Law and Economics, 47(2), 395-430.

Marouani, M. A., \& Munro, L. (2009). Assessing barriers to trade in Services in the Mena Region (No. 84). OECD Publishing.

North, D. C. (1990). Institutions, Institutional Change and Economic Performance. Cambridge university press.

Parker, D., \& Saal, D. S. (Eds.). (2003). International handbook on privatization. Edward Elgar Publishing.

Quinn, D. P. (2000). Democracy and international financial liberalization. McDonough School of Business, Georgetown University. 
Ros, A. J. (1999). Does ownership or competition matter? The effects of telecommunications reform on network expansion and efficiency. Journal of Regulatory Economics, 15(1), 65-92.

Ros, A. J. (2003). The impact of the regulatory process and price cap regulation in Latin American telecommunications markets. Review of Network Economics, 2(3).

Rossotto, C. M., Sekkat, K., \& Varoudakis, A. (2005). Opening up telecommunications to competition and MENA integration in the world economy. Journal of International Development, 17(7), 931-955.

Spiller, P. T. (1993). Institutions and regulatory commitment in utilities' privatization. Industrial and Corporate Change, 2(1), 387-450.

Trillas, F., \& Montoya, M. A. (2011). Commitment and regulatory independence in practice in Latin American and Caribbean Countries. Competition and Regulation in Network Industries, 12(1), $27-57$

Vickers, J., \& Yarrow, G. (1991). Economic perspectives on privatization. The Journal of Economic Perspectives, 111-132.

Wallsten, S. (2003). Of carts and horses: regulation and privatization in telecommunications reforms. Policy Reform, 6(4), 217-231.

Wallsten, S. J. (2001). An econometric analysis of telecom competition, privatization, and regulation in Africa and Latin America. The Journal of industrial economics, 49(1), 1-19.

World Development Indicators Database. (2013). http://data.worldbank.org/data-catalog/worlddevelopment-indicators. Accessed Octobre 2012.

Wooldridge, J. M. (2010). Econometric analysis of cross section and panel data. MIT press. 


\section{Appendix. The effect of telecom reforms on telecom penetration}

Figure 1.1.

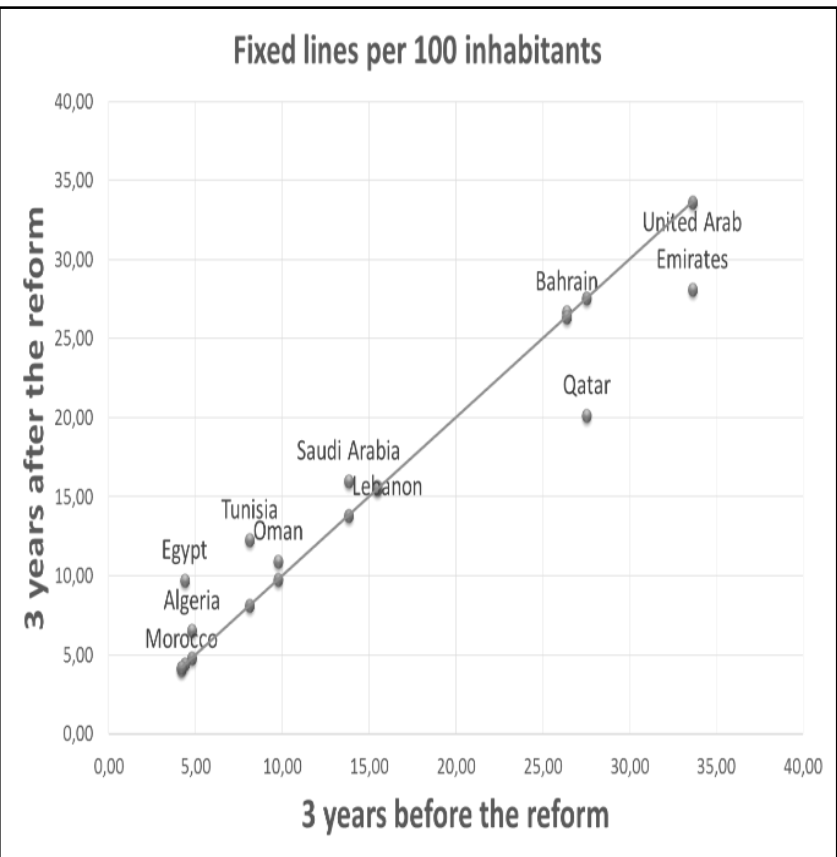

Figure 1.3.

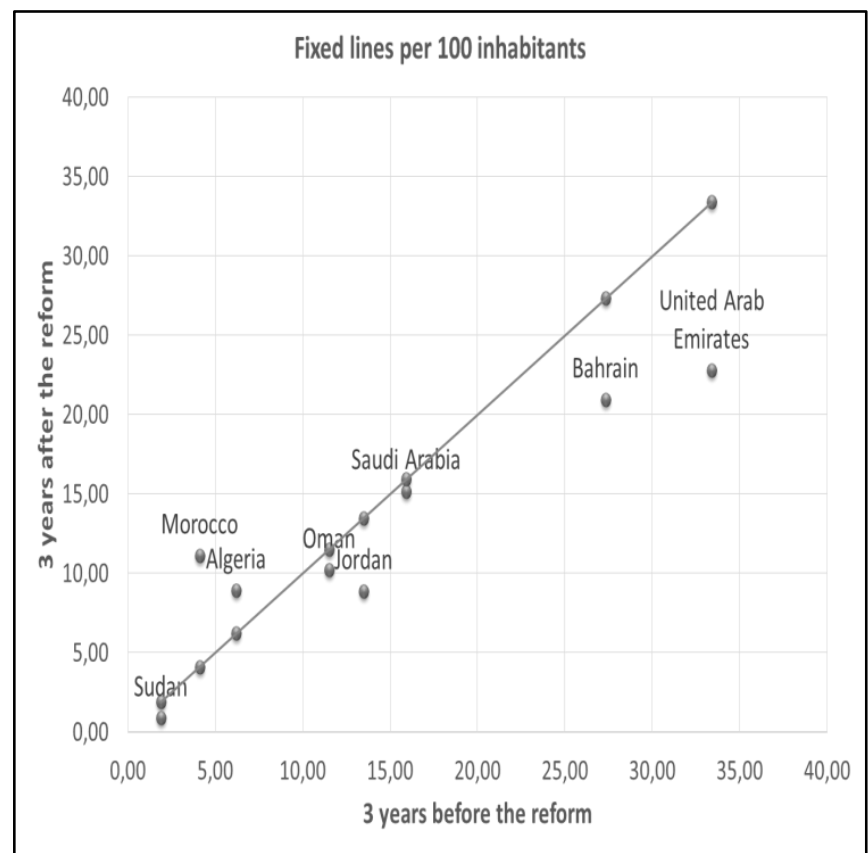

Figure 1.2.

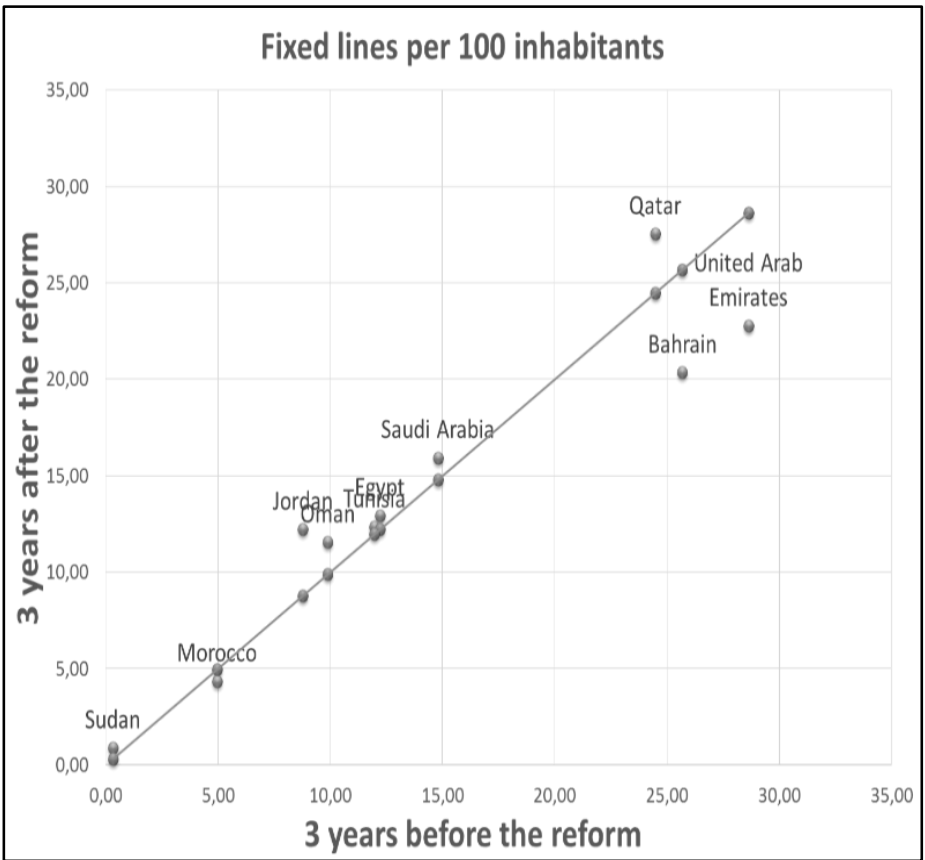

Figure 1.4

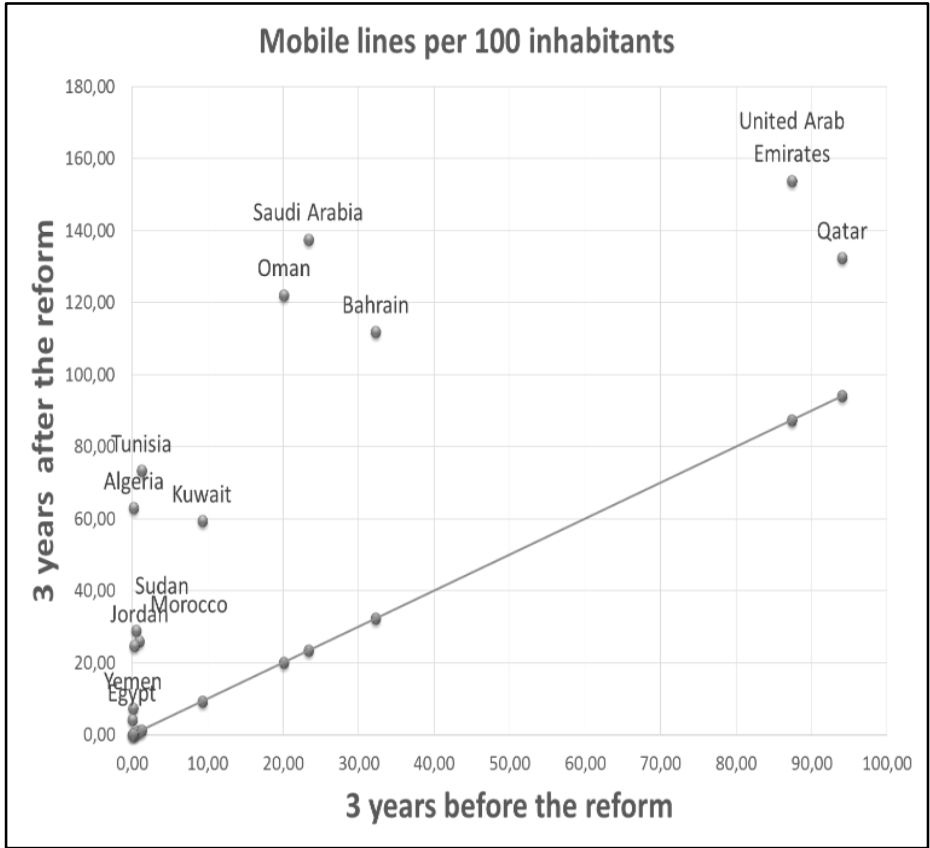

Note. Figure 1.1.The effect of an independent regulator on fixed-line penetration three years before its establishment compared to three years after its establishment. Figure 1.2. The effect of the incumbent's privatization on fixed-line penetration three years before its privatization compared to three years after its privatization. Figure 1.3. The effect of the fixed-line market's liberalization on fixed-line penetration three years before its liberalization compared to three years after its liberalization. Figure 1.4. The effect of the mobile market's liberalization on mobile penetration three years before its liberalization compared to three years after its liberalization. 
Table 1. MENA telecom sector summary 2010

\begin{tabular}{|c|c|c|c|c|}
\hline & $\begin{array}{c}\text { Regulatory } \\
\text { authority } \\
\text { (creation year) }\end{array}$ & $\begin{array}{l}\text { Privatization of the } \\
\text { main incumbent } \\
\text { operator }\end{array}$ & $\begin{array}{l}\text { Competition level } \\
\text { in the fixed-line } \\
\text { telephone market }\end{array}$ & $\begin{array}{l}\text { Competition level } \\
\text { in the mobile } \\
\text { cellular market }\end{array}$ \\
\hline Algeria & 2000 & State-owned & Monopoly & 3 operators \\
\hline Bahrain & 2002 & Partially private & More than 6 & 3 operators \\
\hline Djibouti & $\begin{array}{l}\text { No independent } \\
\text { regulator }\end{array}$ & State-owned & Monopoly & Monopoly \\
\hline Egypt & 1998 & Partially private & Monopoly & 3 operators \\
\hline Jordan & 1995 & Fully private & 2 operators & 3 operators \\
\hline Kuwait & $\begin{array}{l}\text { No independent } \\
\text { regulator }\end{array}$ & State-owned & Monopoly & 3 operators \\
\hline Lebanon & 2002 & State-owned & Monopoly & $\begin{array}{c}\text { Government owned } \\
\text { duopoly }\end{array}$ \\
\hline Libya & 2006 & State-owned & Monopoly & $\begin{array}{c}\text { Government owned } \\
\text { duopoly }\end{array}$ \\
\hline Morocco & 1998 & Privatized & 3 operators & 3 operators \\
\hline Oman & 2002 & Partially private & 2 operators & 2 operators \\
\hline Qatar & 2004 & Partially private & Monopoly & 2 operators \\
\hline $\begin{array}{c}\text { Saudi } \\
\text { Arabia }\end{array}$ & 2002 & Partially private & 2 operators & 4 operators \\
\hline Sudan & 1996 & Partially private & 2 operators & 3 operators \\
\hline Syria & $\begin{array}{l}\text { No independent } \\
\text { regulator }\end{array}$ & State-owned & Monopoly & Controlled Duopoly \\
\hline Tunisia & 2001 & Partially private & Monopoly & 3 operators \\
\hline $\begin{array}{c}\text { United } \\
\text { Arab } \\
\text { Emirates }\end{array}$ & 2003 & Partially private & 2 operators & 2 operators \\
\hline Yemen & $\begin{array}{l}\text { No independent } \\
\text { regulator }\end{array}$ & State-owned & Monopoly & 4 operators \\
\hline
\end{tabular}

Note. Source: By the author from various sources, such as the ITU database, different regulators' websites, incumbent operators' websites and the websites of Ministries of Communication.

Table 2. MENA telecom penetration

\begin{tabular}{cccc}
\hline Country & $\begin{array}{c}\text { Number of } \\
\text { mainlines per 100 } \\
\text { people (1995) }\end{array}$ & $\begin{array}{c}\text { Number of mainlines } \\
\text { per 100 people (2011) }\end{array}$ & $\begin{array}{c}\text { Number of cellular lines } \\
\text { per 100 people (2011) }\end{array}$ \\
\hline $\begin{array}{c}\text { MENA average } \\
\text { Low \& middle } \\
\text { income }\end{array}$ & 10.2 & 12.7 & 112.2 \\
$\begin{array}{c}\text { Latin America \& } \\
\text { Caribbean (all } \\
\text { income levels) }\end{array}$ & 6.6 & 10.81 & 92.73 \\
$\begin{array}{c}\text { East Asia \& Pacific } \\
\text { (all income levels) } \\
\text { OECD members }\end{array}$ & 8.98 & 17.88 & 104.72 \\
\hline
\end{tabular}

Note. Source: World Development Indicators (2013) 
Table 3 Variables list

Variables

\section{Dependent variables}

\begin{tabular}{|c|c|c|}
\hline Variables & Description & Source of the data \\
\hline \multicolumn{3}{|c|}{ Dependent variables } \\
\hline \multirow[t]{2}{*}{ Access } & $\begin{array}{c}\text { Log (the number of fixed lines in a country per } 100 \\
\text { inhabitants) }\end{array}$ & The ITU database \\
\hline & $\begin{array}{c}\log \text { (the number of mobile lines in a country per } 100 \\
\text { inhabitants) }\end{array}$ & The ITU database \\
\hline Productivity & $\begin{array}{l}\log \{\text { the number of telephone subscribers for fixed-line } \\
\text { and mobile telephones per employee (Total full-time } \\
\text { telecommunication employees) }\}\end{array}$ & The ITU database \\
\hline \multirow[t]{3}{*}{ Prices } & $\begin{array}{c}\log \text { (the monthly subscription for residential telephone } \\
\text { service) }\end{array}$ & The ITU database \\
\hline & $\begin{array}{l}\text { Log (the price of a 3-minute fixed-line telephone local call } \\
\text { (off-peak rate) in US\$) }\end{array}$ & The ITU database \\
\hline & $\log$ (the mobile price of 3-minute local (off-peak) in US\$) & The ITU database \\
\hline \multicolumn{3}{|l|}{ Reforms variables } \\
\hline & Regulation dummy variable & $\begin{array}{l}\text { ITU database and different } \\
\text { regulators websites }\end{array}$ \\
\hline & Privatization dummy variable & $\begin{array}{l}\text { By the author from ITU, incumbents } \\
\text { operators' websites and Ministries } \\
\text { of communications websites per } \\
\text { country }\end{array}$ \\
\hline & Competition index & $\begin{array}{l}\text { By the author from ITU, different } \\
\text { regulators and operators' websites } \\
\text { and Ministries of communications } \\
\text { websites per country }\end{array}$ \\
\hline \multicolumn{3}{|l|}{ Control variables } \\
\hline & Log (GDP per capita) & $\begin{array}{l}\text { WDI (World Development } \\
\text { Indicators), the World Bank }\end{array}$ \\
\hline & Log (population density) & $\begin{array}{l}\text { WDI (World Development } \\
\text { Indicators), the World Bank }\end{array}$ \\
\hline
\end{tabular}

Description

Source of the data

\section{Instrumental Variables}

Polity IV Project's political regime indicator for democracy

The Center for Systemic Peace website ("Polity IV")

Legal origins — civil law or common—dummy variable The CIA World Factbook

Total natural resources rents (\% of GDP)

WDI (World Development Indicators), the World Bank

The year of independence

The CIA World Factbook 
Table 4. Summary statistics

\begin{tabular}{|c|c|c|c|c|c|c|c|}
\hline \multirow[b]{2}{*}{ Variable } & \multicolumn{7}{|c|}{$\begin{array}{c}\text { Mean } \\
\text { (Standard Deviation, Number of observations) }\end{array}$} \\
\hline & $\begin{array}{l}\text { For the } \\
\text { whole } \\
\text { sample } \\
\end{array}$ & $\begin{array}{l}\text { When } \\
\text { IRA }=0\end{array}$ & $\begin{array}{l}\text { When } \\
\text { IRA = 1 }\end{array}$ & $\begin{array}{c}\text { When } \\
\text { Privatization }= \\
0 \\
\end{array}$ & $\begin{array}{c}\text { When } \\
\text { Privatization } \\
=1\end{array}$ & $\begin{array}{c}\text { When } \\
\text { Competition }= \\
0 \\
\end{array}$ & $\begin{array}{c}\text { When } \\
\text { Competition } \\
>=1 \\
\end{array}$ \\
\hline \multicolumn{8}{|l|}{ Access indicators } \\
\hline Fixed per 100 inhabitants & $\begin{array}{c}12.84 \\
(8.68,272)\end{array}$ & $\begin{array}{c}13.23 \\
(9.58,143)\end{array}$ & $\begin{array}{c}12.41 \\
(7.57,129)\end{array}$ & $\begin{array}{c}10.7 \\
(6.77,166)\end{array}$ & $\begin{array}{c}16.20 \\
(10.19,106)\end{array}$ & $\begin{array}{c}13.13 \\
(9.51,164)\end{array}$ & $\begin{array}{c}12.4 \\
(7.26,108)\end{array}$ \\
\hline Mobile per 100 inhabitants & $\begin{array}{c}37.31 \\
(45.24,272)\end{array}$ & $\begin{array}{c}20.63 \\
(34.87,143)\end{array}$ & $\begin{array}{c}55.81 \\
(48.27,129)\end{array}$ & $\begin{array}{c}20.8 \\
(34.4,166)\end{array}$ & $\begin{array}{c}63.18 \\
(48.18,106)\end{array}$ & $\begin{array}{c}18.65 \\
(30.6,164)\end{array}$ & $\begin{array}{c}65.66 \\
(49.12,108)\end{array}$ \\
\hline \multicolumn{8}{|c|}{ Productivity indicator } \\
\hline $\begin{array}{l}\text { Total Lines (Fixed and Mobile) } \\
\text { per Employee }\end{array}$ & $\begin{array}{c}367.47 \\
(429.4,217)\end{array}$ & $\begin{array}{c}155.94 \\
(193.28,116)\end{array}$ & $\begin{array}{c}610.42 \\
(493.78,101)\end{array}$ & $\begin{array}{c}171.26 \\
(203.51,125)\end{array}$ & $\begin{array}{c}634.07 \\
(506.47,92)\end{array}$ & $\begin{array}{c}92.16 \\
(51.81,137)\end{array}$ & $\begin{array}{c}687.82 \\
(514.78,80)\end{array}$ \\
\hline \multicolumn{8}{|c|}{$\begin{array}{c}\text { Affordability indicators } \\
\end{array}$} \\
\hline $\begin{array}{l}\text { Monthly subscription for } \\
\text { residential telephone service }\end{array}$ & $\begin{array}{c}5.96 \\
(4.41,235)\end{array}$ & $\begin{array}{c}6.08 \\
(5.06,122)\end{array}$ & $\begin{array}{c}5.84 \\
(3.61,113)\end{array}$ & $\begin{array}{c}5.87 \\
(4.87,137)\end{array}$ & $\begin{array}{c}6.089 \\
(3.71,98)\end{array}$ & $\begin{array}{c}6.21 \\
(4.67,146)\end{array}$ & $\begin{array}{c}5.56 \\
(3.93,89)\end{array}$ \\
\hline $\begin{array}{l}\text { Mobile cellular prepaid-price } \\
\text { of 3-minute local call (off-peak, } \\
\text { on-net) in US\$ }\end{array}$ & $\begin{array}{c}.39 \\
(0.39,213)\end{array}$ & $\begin{array}{c}.37 \\
(0.47,106)\end{array}$ & $\begin{array}{c}.41 \\
(0.37,107)\end{array}$ & $\begin{array}{c}.43 \\
(0.502,123)\end{array}$ & $\begin{array}{c}.34 \\
(0.27,90)\end{array}$ & $\begin{array}{c}.39 \\
(0.37,128)\end{array}$ & $\begin{array}{c}.401 \\
(0.48,85)\end{array}$ \\
\hline $\begin{array}{l}\text { Price of a 3-minute fixed } \\
\text { telephone local call (off-peak } \\
\text { rate) in US\$ }\end{array}$ & $\begin{array}{c}.057 \\
(0.092,228)\end{array}$ & $\begin{array}{c}.039 \\
(0.054,108)\end{array}$ & $\begin{array}{c}.074 \\
(0.11,120)\end{array}$ & $\begin{array}{c}.046 \\
(0.062,131)\end{array}$ & $\begin{array}{c}.073 \\
(0.119,97)\end{array}$ & $\begin{array}{c}.0497 \\
(0.053,128)\end{array}$ & $\begin{array}{c}.068 \\
(0.124,100)\end{array}$ \\
\hline
\end{tabular}

Note. Source: Own calculations from ITU database and collected data.

\section{Mean}

(Standard Deviation, Number of observations)

\begin{tabular}{|c|c|c|c|c|c|c|c|c|}
\hline Variable & $\begin{array}{c}\text { IRA* } \\
\text { Privatizatio } \\
\mathbf{n}=0\end{array}$ & $\begin{array}{c}\text { IRA* } \\
\text { Privatizatio } \\
\mathbf{n}=1\end{array}$ & $\begin{array}{c}\text { Fixed } \\
\text { Competition * } \\
\text { Privatization= } \\
\text { 0 }\end{array}$ & $\begin{array}{c}\text { Fixed } \\
\text { Competition * } \\
\text { Privatization= } \\
1 \\
\end{array}$ & $\begin{array}{c}\text { IRA*Compe } \\
\text { tition } \\
\text { Index }=0\end{array}$ & $\begin{array}{c}\text { IRA } * \text { Com } \\
\text { petition } \\
\text { Index }>=1\end{array}$ & $\begin{array}{l}\text { Three-way } \\
\text { interaction } \\
\quad=0\end{array}$ & $\begin{array}{c}\text { Three-way } \\
\text { interaction } \\
\quad>=1\end{array}$ \\
\hline \multicolumn{9}{|l|}{ Access indicators } \\
\hline Fixed per 100 & 12.66 & 13.23 & 10.7 & 17.52 & 13.2 & 11.67 & 12.8 & 12.97 \\
\hline inhabitants & $(8.66,188)$ & $(8.75,84)$ & $(6.77,166)$ & $(10.5,75)$ & $(9.49,187)$ & $(5.04,51)$ & $(9.1,208)$ & $(7.22,64)$ \\
\hline Mobile per 100 & 21.38 & 72.97 & 20.8 & 49.52 & 22.85 & 53.1 & 23.64 & 81.76 \\
\hline inhabitants & $(33.09,188)$ & $(48.53,84)$ & $(34.4,166)$ & $(48.87,75)$ & $(35.24,187)$ & $(42.39,51)$ & $(35.04,208)$ & $(46.34,64)$ \\
\hline \multicolumn{9}{|c|}{ Productivity indicator } \\
\hline $\begin{array}{l}\text { Total lines (Fixed and } \\
\text { Mobile) per Employee }\end{array}$ & $\begin{array}{c}173.3 \\
(190.57 \\
147)\end{array}$ & $\begin{array}{c}775.24 \\
(501.38,70)\end{array}$ & $\begin{array}{c}171.26 \\
(203.51,125)\end{array}$ & $\begin{array}{c}476.47 \\
(354.9,71)\end{array}$ & $\begin{array}{c}191.7 \\
(213.9,150)\end{array}$ & $\begin{array}{c}590.12 \\
(372,44)\end{array}$ & $\begin{array}{c}200.72 \\
(211.46 \\
167)\end{array}$ & $\begin{array}{c}924.45 \\
(500.04,50)\end{array}$ \\
\hline \multicolumn{9}{|c|}{ Affordability indicators } \\
\hline $\begin{array}{l}\text { Monthly subscription for } \\
\text { residential telephone } \\
\text { service }\end{array}$ & $\begin{array}{c}5.86 \\
(4.7,159)\end{array}$ & $\begin{array}{c}6.18 \\
(3.75,76)\end{array}$ & $\begin{array}{c}5.87 \\
(4.87,137)\end{array}$ & $\begin{array}{c}5.85 \\
(3.42,70)\end{array}$ & $\begin{array}{c}5.96 \\
(4.64,166)\end{array}$ & $\begin{array}{c}5.77 \\
(3.4,38)\end{array}$ & $\begin{array}{c}5.73 \\
(4.57,179)\end{array}$ & $\begin{array}{c}6.71 \\
(3.83,56)\end{array}$ \\
\hline $\begin{array}{l}\text { Mobile cellular prepaid- } \\
\text { price of 3-minute local } \\
\text { call (off-peak, on-net) in } \\
\text { US\$ }\end{array}$ & $\begin{array}{c}0.41 \\
(0.47,145)\end{array}$ & $\begin{array}{c}0.36 \\
(0.29,68)\end{array}$ & $\begin{array}{c}.43 \\
(0.502,123)\end{array}$ & $\begin{array}{c}0.31 \\
(0.18,69)\end{array}$ & $\begin{array}{c}0.4 \\
(0.47,146)\end{array}$ & $\begin{array}{c}.355 \\
(0.2,44)\end{array}$ & $\begin{array}{c}0.39 \\
(0.45,164)\end{array}$ & $\begin{array}{c}0.4 \\
(0.33,49)\end{array}$ \\
\hline $\begin{array}{l}\text { Price of a 3-minute fixed } \\
\text { telephone local call (off- } \\
\text { peak rate) in US\$ }\end{array}$ & $\begin{array}{c}.044 \\
(0.06,149)\end{array}$ & $\begin{array}{c}.084 \\
(0.13,79)\end{array}$ & $\begin{array}{c}.046 \\
(0.062,131)\end{array}$ & $\begin{array}{c}.069 \\
(0.13,69)\end{array}$ & $\begin{array}{c}.044 \\
(0.52,147)\end{array}$ & $\begin{array}{c}.086 \\
(0.16,50)\end{array}$ & $\begin{array}{c}0.045 \\
(0.06,168)\end{array}$ & $\begin{array}{c}0.095 \\
(0.33,49)\end{array}$ \\
\hline
\end{tabular}


Table 5. OLS estimation "The separate effects of each reform variable"

\begin{tabular}{|c|c|c|c|c|c|c|}
\hline & \multicolumn{2}{|c|}{ ACCESS } & PRODUCTIVITY & \multicolumn{3}{|c|}{ AFFORDABILITY } \\
\hline VARIABLES & $\begin{array}{c}\text { Fixed per } \\
100 \\
\text { inhabitant } \\
\text { s (in log) }\end{array}$ & $\begin{array}{l}\text { Mobile per } 100 \\
\text { inhabitants (in } \\
\quad \log )\end{array}$ & $\begin{array}{l}\text { Total number of } \\
\text { Lines per } \\
\text { employee (in log) }\end{array}$ & $\begin{array}{c}\text { Monthly } \\
\text { subscription } \\
\text { for } \\
\text { residential } \\
\text { telephone } \\
\text { service }\end{array}$ & $\begin{array}{l}\text { Price of } 3 \text { - } \\
\text { minute fixed } \\
\text { local call (off- } \\
\text { peak) (in log) }\end{array}$ & $\begin{array}{l}\text { Mobile price of } \\
\text { 3-minute local } \\
\text { call (off-peak) } \\
\text { (in log) }\end{array}$ \\
\hline \multirow[t]{2}{*}{ IRA establishment } & $-0.127 * *$ & $-0.601 * * *$ & $-0.154 * *$ & -0.113 & $0.278 * *$ & 0.112 \\
\hline & $(0.0549)$ & $(0.206)$ & $(0.0652)$ & $(0.0980)$ & $(0.138)$ & $(0.173)$ \\
\hline \multirow[t]{2}{*}{ Population density } & $-0.687 * * *$ & $-1.454 *$ & 0.211 & 0.182 & $-2.963 * * *$ & $-1.631 * *$ \\
\hline & $(0.216)$ & $(0.805)$ & $(0.291)$ & $(0.371)$ & $(0.918)$ & $(0.703)$ \\
\hline \multirow[t]{2}{*}{ GDP per capita } & 0.305 & $2.542 * * *$ & $1.451 * * *$ & $0.771^{*}$ & -0.888 & -1.287 \\
\hline & $(0.240)$ & $(0.925)$ & $(0.318)$ & $(0.427)$ & $(0.783)$ & $(0.823)$ \\
\hline Observations & 260 & 255 & 207 & 225 & 193 & 202 \\
\hline R-squared & 0.468 & 0.866 & 0.937 & 0.103 & 0.236 & 0.112 \\
\hline \multicolumn{7}{|c|}{$\begin{array}{l}\text { Note. Fixed effects OLS estimation. The Hausman test's null hypothesis is rejected; the difference between random-effects estimates } \\
\text { and fixed-effects estimates is systematic, and we should use the fixed-effects estimates. Year dummies and constant terms are not } \\
\text { reported. } * * * \mathrm{p}<0.01, * * \mathrm{p}<0.05,{ }^{*} \mathrm{p}<0.1 \text {. }\end{array}$} \\
\hline \multirow[t]{2}{*}{ Privatization } & $-0.110^{*}$ & -0.0524 & $0.127 *$ & $0.213^{*}$ & 0.147 & $-0.407 * *$ \\
\hline & $(0.0614)$ & $(0.230)$ & $(0.0766)$ & $(0.111)$ & $(0.146)$ & $(0.181)$ \\
\hline \multirow[t]{2}{*}{ Population density } & $-0.818 * * *$ & $-1.688 * *$ & 0.208 & 0.234 & $-2.970 * * *$ & $-1.830 * * *$ \\
\hline & $(0.218)$ & $(0.829)$ & $(0.298)$ & $(0.370)$ & $(0.929)$ & (0.699) \\
\hline \multirow[t]{2}{*}{ GDP per capita } & 0.301 & $2.641 * * *$ & $1.369 * * *$ & $0.720 *$ & -0.987 & -1.300 \\
\hline & $(0.241)$ & $(0.942)$ & $(0.319)$ & $(0.425)$ & $(0.791)$ & $(0.809)$ \\
\hline Observations & 260 & 255 & 207 & 225 & 193 & 202 \\
\hline R-squared & 0.463 & 0.861 & 0.936 & 0.114 & 0.222 & 0.135 \\
\hline
\end{tabular}

Note. Fixed-effects OLS estimation. The Hausman test's null hypothesis is rejected; the difference between random-effects estimates and fixed-effects estimates is systematic, and we should use the fixed-effects estimates. Year dummies and constant terms are not reported. $* * * \mathrm{p}<0.01, * * \mathrm{p}<0.05, * \mathrm{p}<0.1$

\begin{tabular}{|c|c|c|c|c|c|c|}
\hline Competition index & $\begin{array}{c}-0.0819 * * \\
(0.0357)\end{array}$ & $\begin{array}{c}0.268 * * \\
(0.134)\end{array}$ & $\begin{array}{c}0.0220 \\
(0.0476)\end{array}$ & $\begin{array}{c}0.0963 \\
(0.0649)\end{array}$ & $\begin{array}{c}0.0896 \\
(0.0996)\end{array}$ & $\begin{array}{r}-0.0318 \\
(0.112)\end{array}$ \\
\hline Population density & $\begin{array}{c}-0.637 * * * \\
(0.220)\end{array}$ & $\begin{array}{c}-1.992 * * \\
(0.827)\end{array}$ & $\begin{array}{l}0.0683 \\
(0.291)\end{array}$ & $\begin{array}{c}0.00717 \\
(0.376)\end{array}$ & $\begin{array}{c}-3.527 * * * \\
(1.068)\end{array}$ & $\begin{array}{c}-1.551 * * \\
(0.719)\end{array}$ \\
\hline GDP per capita & $\begin{array}{c}0.355 \\
(0.242) \\
\end{array}$ & $\begin{array}{c}2.482 * * * \\
(0.937)\end{array}$ & $\begin{array}{c}1.361 * * * \\
(0.322)\end{array}$ & $\begin{array}{c}0.690 \\
(0.429)\end{array}$ & $\begin{array}{l}-1.243 \\
(0.857)\end{array}$ & $\begin{array}{l}-1.298 \\
(0.827)\end{array}$ \\
\hline Observations & 260 & 255 & 207 & 225 & 193 & 202 \\
\hline R-squared & 0.468 & 0.864 & 0.935 & 0.107 & 0.221 & 0.110 \\
\hline
\end{tabular}

Note. Fixed-effects OLS estimation. The Hausman test's null hypothesis is rejected; the difference between random-effects estimates and fixed-effects estimates is systematic, and we should use the fixed-effects estimates. Year dummies and constant terms are not reported. $* * * \mathrm{p}<0.01, * * \mathrm{p}<0.05, * \mathrm{p}<0.1$

\begin{tabular}{|c|c|c|c|c|c|c|}
\hline Fixed competition & $\begin{array}{c}-0.131 * * \\
(0.0602)\end{array}$ & $\begin{array}{c}-0.0225 \\
(0.225)\end{array}$ & $\begin{array}{c}-0.00604 \\
(0.0827)\end{array}$ & $\begin{array}{l}0.209 * \\
(0.107)\end{array}$ & $\begin{array}{l}0.0193 \\
(0.164)\end{array}$ & $\begin{array}{l}-0.113 \\
(0.190)\end{array}$ \\
\hline Population density & $\begin{array}{c}-0.681 * * * \\
(0.216)\end{array}$ & $\begin{array}{c}-1.645 * * \\
(0.824)\end{array}$ & $\begin{array}{l}0.0816 \\
(0.291)\end{array}$ & $\begin{array}{l}0.0224 \\
(0.370)\end{array}$ & $\begin{array}{c}-3.110 * * * \\
(1.062)\end{array}$ & $\begin{array}{c}-1.513 * * \\
(0.715)\end{array}$ \\
\hline GDP per capita & $\begin{array}{c}0.321 \\
(0.241)\end{array}$ & $\begin{array}{c}2.640 * * * \\
(0.942)\end{array}$ & $\begin{array}{c}1.370 * * * \\
(0.322)\end{array}$ & $\begin{array}{l}0.706^{*} \\
(0.425)\end{array}$ & $\begin{array}{l}-0.983 \\
(0.858)\end{array}$ & $\begin{array}{l}-1.268 \\
(0.826)\end{array}$ \\
\hline Observations & 260 & 255 & 207 & 225 & 193 & 202 \\
\hline R-squared & 0.466 & 0.861 & 0.935 & 0.114 & 0.217 & 0.111 \\
\hline \multicolumn{7}{|c|}{$\begin{array}{l}\text { Note. Fixed-effects OLS estimation. The Hausman test's null hypothesis is rejected; the difference between random-effects estimates } \\
\text { and fixed-effects estimates is systematic, and we should use the fixed-effects estimates. Year dummies and constant terms are not } \\
\text { reported. } * * * \mathrm{p}<0.01, * * \mathrm{p}<0.05, * \mathrm{p}<0.1 \text {. }\end{array}$} \\
\hline Mobile competition & $\begin{array}{c}-0.0831 * \\
(0.0501)\end{array}$ & $\begin{array}{c}0.481 * * \\
(0.185)\end{array}$ & $\begin{array}{l}-0.0204 \\
(0.0593)\end{array}$ & $\begin{array}{c}0.0266 \\
(0.0883)\end{array}$ & $\begin{array}{l}0.0799 \\
(0.128)\end{array}$ & $\begin{array}{c}0.00162 \\
(0.148)\end{array}$ \\
\hline Population density & $\begin{array}{c}-0.663 * * * \\
(0.222)\end{array}$ & $\begin{array}{c}-2.146 * * \\
(0.827)\end{array}$ & $\begin{array}{l}0.0908 \\
(0.292)\end{array}$ & $\begin{array}{c}0.103 \\
(0.379)\end{array}$ & $\begin{array}{c}-3.248 * * * \\
(0.980)\end{array}$ & $\begin{array}{c}-1.597 * * \\
(0.716)\end{array}$ \\
\hline GDP per capita & $\begin{array}{c}0.365 \\
(0.246)\end{array}$ & $\begin{array}{l}2.235 * * \\
(0.940)\end{array}$ & $\begin{array}{c}1.385 * * * \\
(0.324)\end{array}$ & $\begin{array}{l}0.737 * \\
(0.435)\end{array}$ & $\begin{array}{l}-1.092 \\
(0.825)\end{array}$ & $\begin{array}{l}-1.328 \\
(0.831)\end{array}$ \\
\hline Observations & 260 & 255 & 207 & 225 & 193 & 202 \\
\hline R-squared & 0.462 & 0.865 & 0.935 & 0.097 & 0.219 & 0.109 \\
\hline
\end{tabular}

Note. Fixed-effects OLS estimation. The Hausman test's null hypothesis is rejected; the difference between random-effects estimates and fixed-effects estimates is systematic, and we should use the fixed-effects estimates. Year dummies and constant terms are not reported. $* * * \mathrm{p}<0.01, * * \mathrm{p}<0.05, * \mathrm{p}<0.1$. 
Table 6. OLS estimation "The effect of different reforms interactions"

\begin{tabular}{|c|c|c|c|c|c|c|}
\hline \multirow[b]{2}{*}{ VARIABLES } & \multicolumn{2}{|c|}{ ACCESS } & \multirow[b]{2}{*}{$\begin{array}{l}\text { PRODUCTIVITY } \\
\text { Total number of } \\
\text { Lines per employee } \\
\text { (in log) }\end{array}$} & \multicolumn{3}{|c|}{ AFFORDABILITY } \\
\hline & $\begin{array}{l}\text { Fixed per } 100 \\
\text { inhabitants (in } \\
\log )\end{array}$ & $\begin{array}{l}\text { Mobile per } 100 \\
\text { inhabitants (in } \\
\log )\end{array}$ & & $\begin{array}{c}\text { Monthly } \\
\text { subscription } \\
\text { for } \\
\text { residential } \\
\text { telephone } \\
\text { service }\end{array}$ & $\begin{array}{c}\text { Price of 3- } \\
\text { minute fixed } \\
\text { local call (off- } \\
\text { peak rate) (in } \\
\text { log) }\end{array}$ & $\begin{array}{l}\text { Mobile price } \\
\text { of 3-minute } \\
\text { local call (off- } \\
\text { peak) in US\$ } \\
\text { (in log) }\end{array}$ \\
\hline IRA establishment & $\begin{array}{c}-0.0969 \\
(0.0646)\end{array}$ & $\begin{array}{c}-0.220 \\
(0.237)\end{array}$ & $\begin{array}{l}-0.141^{*} \\
(0.0774)\end{array}$ & $\begin{array}{c}-0.0706 \\
(0.115)\end{array}$ & $\begin{array}{c}0.368^{* *} \\
(0.161)\end{array}$ & $\begin{array}{l}0.338^{*} \\
(0.201)\end{array}$ \\
\hline Privatization & $\begin{array}{r}-0.0387 \\
(0.115)\end{array}$ & $\begin{array}{c}1.235 * * * \\
(0.434)\end{array}$ & $\begin{array}{l}0.245^{*} \\
(0.131)\end{array}$ & $\begin{array}{c}0.413 * * \\
(0.196)\end{array}$ & $\begin{array}{c}0.454 \\
(0.303)\end{array}$ & $\begin{array}{c}0.150 \\
(0.340)\end{array}$ \\
\hline IRA* Privatization & $\begin{array}{l}-0.0597 \\
(0.110)\end{array}$ & $\begin{array}{c}-1.335 * * * \\
(0.413)\end{array}$ & $\begin{array}{l}-0.102 \\
(0.126)\end{array}$ & $\begin{array}{l}-0.209 \\
(0.188)\end{array}$ & $\begin{array}{l}-0.376 \\
(0.296)\end{array}$ & $\begin{array}{l}-0.626^{*} \\
(0.321)\end{array}$ \\
\hline Population density & $\begin{array}{c}-0.674 * * * \\
(0.257)\end{array}$ & $\begin{array}{c}0.136 \\
(0.938)\end{array}$ & $\begin{array}{c}0.524 \\
(0.344)\end{array}$ & $\begin{array}{c}0.568 \\
(0.439)\end{array}$ & $\begin{array}{c}-2.250 * * \\
(1.055)\end{array}$ & $\begin{array}{l}-1.022 \\
(0.823)\end{array}$ \\
\hline GDP per capita & $\begin{array}{c}0.340 \\
(0.245) \\
\end{array}$ & $\begin{array}{c}2.968 * * * \\
(0.917)\end{array}$ & $\begin{array}{c}1.515 * * * \\
(0.322)\end{array}$ & $\begin{array}{l}0.828 * \\
(0.432)\end{array}$ & $\begin{array}{c}-0.544 \\
(0.839) \\
\end{array}$ & $\begin{array}{c}-0.898 \\
(0.826) \\
\end{array}$ \\
\hline Observations & 260 & 255 & 207 & 225 & 193 & 202 \\
\hline R-squared & 0.474 & 0.872 & 0.939 & 0.129 & 0.247 & 0.158 \\
\hline
\end{tabular}

Note. Fixed-effects OLS estimation. The Hausman test's null hypothesis is rejected; the difference between random-effects estimates and fixed-effects estimates is systematic, and we should use the fixed-effects estimates. Year dummies and constant terms are not reported. $* * * p<0.01, * * p<0.05, *$ $\mathrm{p}<0.1$.

\begin{tabular}{|c|c|c|c|c|c|c|}
\hline Privatization & $\begin{array}{c}-0.104 * \\
(0.0610)\end{array}$ & $\begin{array}{l}0.0141 \\
(0.227)\end{array}$ & $\begin{array}{c}0.0896 \\
(0.0762)\end{array}$ & $\begin{array}{l}0.201 * \\
(0.110)\end{array}$ & $\begin{array}{c}0.151 \\
(0.148)\end{array}$ & $\begin{array}{c}-0.420 * * \\
(0.183)\end{array}$ \\
\hline Fixed competition & $\begin{array}{l}0.0780 \\
(0.154)\end{array}$ & $\begin{array}{c}1.642 * * * \\
(0.567)\end{array}$ & $\begin{array}{c}-0.721 * * * \\
(0.203)\end{array}$ & $\begin{array}{l}-0.113 \\
(0.257)\end{array}$ & $\begin{array}{l}-0.0266 \\
(0.337)\end{array}$ & $\begin{array}{l}0.0689 \\
(0.487)\end{array}$ \\
\hline $\begin{array}{l}\text { Fixed Competition * } \\
\text { Privatization }\end{array}$ & -0.242 & $-1.907 * * *$ & $0.831 * * *$ & 0.377 & 0.0853 & -0.265 \\
\hline Population density & $\begin{array}{c}(0.162) \\
-0.716^{* * *} \\
(0.219)\end{array}$ & $\begin{array}{l}(0.598) \\
-1.440^{*} \\
(0.824)\end{array}$ & $\begin{array}{l}(0.208) \\
0.0188 \\
(0.290)\end{array}$ & $\begin{array}{l}(0.271) \\
0.0811 \\
(0.372)\end{array}$ & $\begin{array}{c}(0.364) \\
-3.159 * * * \\
(1.095)\end{array}$ & $\begin{array}{c}(0.508) \\
-1.687 * * \\
(0.715)\end{array}$ \\
\hline GDP per capita & $\begin{array}{c}0.341 \\
(0.239)\end{array}$ & $\begin{array}{c}2.678 * * * \\
(0.925)\end{array}$ & $\begin{array}{c}1.294 * * * \\
(0.307)\end{array}$ & $\begin{array}{c}0.660 \\
(0.422)\end{array}$ & $\begin{array}{l}-1.103 \\
(0.874)\end{array}$ & $\begin{array}{l}-1.207 \\
(0.818)\end{array}$ \\
\hline Observations & 260 & 255 & 207 & 225 & 193 & 202 \\
\hline R-squared & 0.479 & 0.867 & 0.941 & 0.141 & 0.223 & 0.141 \\
\hline
\end{tabular}

Note. Fixed-effects OLS estimation. The Hausman test's null hypothesis is rejected; the difference between random-effects estimates and fixed-effects estimates is systematic, and we should use the fixed-effects estimates. Year dummies and constant terms are not reported. $* * * p<0.01, * * p<0.05, *$

\begin{tabular}{|c|c|c|c|c|c|c|}
\hline IRA establishment & $\begin{array}{c}-0.0737 \\
(0.0580)\end{array}$ & $\begin{array}{c}-0.793 * * * \\
(0.220)\end{array}$ & $\begin{array}{l}-0.158 * * \\
(0.0692)\end{array}$ & $\begin{array}{l}-0.195^{*} \\
(0.102)\end{array}$ & $\begin{array}{l}0.252 * \\
(0.149)\end{array}$ & $\begin{array}{c}0.201 \\
(0.182)\end{array}$ \\
\hline Competition Index & $\begin{array}{c}0.124 \\
(0.103)\end{array}$ & $\begin{array}{l}-0.422 \\
(0.387)\end{array}$ & $\begin{array}{l}0.0502 \\
(0.125)\end{array}$ & $\begin{array}{l}-0.301 \\
(0.182)\end{array}$ & $\begin{array}{l}-0.0297 \\
(0.304)\end{array}$ & $\begin{array}{c}0.482 \\
(0.331)\end{array}$ \\
\hline IRA*Competition Index & $\begin{array}{c}-0.207 * * \\
(0.101)\end{array}$ & $\begin{array}{l}0.739 * \\
(0.376)\end{array}$ & $\begin{array}{c}-0.0149 \\
(0.124)\end{array}$ & $\begin{array}{c}0.418^{* * *} \\
(0.179)\end{array}$ & $\begin{array}{l}0.0837 \\
(0.299)\end{array}$ & $\begin{array}{l}-0.538 \\
(0.327)\end{array}$ \\
\hline Population density & $\begin{array}{c}-0.617 * * * \\
(0.218)\end{array}$ & $\begin{array}{c}-1.739 * * \\
(0.809)\end{array}$ & $\begin{array}{c}0.197 \\
(0.293)\end{array}$ & $\begin{array}{c}0.110 \\
(0.375)\end{array}$ & $\begin{array}{c}-3.228 * * * \\
(1.075)\end{array}$ & $\begin{array}{c}-1.600 * * \\
(0.719)\end{array}$ \\
\hline GDP per capita & $\begin{array}{c}0.391 \\
(0.239) \\
\end{array}$ & $\begin{array}{c}2.207 * * \\
(0.917) \\
\end{array}$ & $\begin{array}{c}1.444 * * * \\
(0.321)\end{array}$ & $\begin{array}{c}0.652 \\
(0.424)\end{array}$ & $\begin{array}{l}-1.070 \\
(0.859) \\
\end{array}$ & $\begin{array}{l}-1.094 \\
(0.833)\end{array}$ \\
\hline Observations & 260 & 255 & 207 & 225 & 193 & 202 \\
\hline R-squared & 0.487 & 0.872 & 0.937 & 0.138 & 0.238 & 0.126 \\
\hline
\end{tabular}

Note. Fixed-effects OLS estimation. The Hausman test's null hypothesis is rejected; the difference between random-effects estimates and fixed-effects estimates is systematic, and we should use the fixed-effects estimates. Year dummies and constant terms are not reported. $* * * \mathrm{p}<0.01, * * \mathrm{p}<0.05, *$ $\mathrm{p}<0.1$.

\begin{tabular}{|c|c|c|c|c|c|c|}
\hline Three-way interaction & $\begin{array}{c}-0.128 * * * \\
(0.0351)\end{array}$ & $\begin{array}{l}-0.113 \\
(0.134)\end{array}$ & $\begin{array}{c}0.0973 * * \\
(0.0490)\end{array}$ & $\begin{array}{l}0.156 * * \\
(0.0637)\end{array}$ & $\begin{array}{l}0.0807 \\
(0.103)\end{array}$ & $\begin{array}{l}-0.149 \\
(0.113)\end{array}$ \\
\hline Population density & $\begin{array}{c}-0.575 * * * \\
(0.216)\end{array}$ & $\begin{array}{l}-1.510 * \\
(0.834)\end{array}$ & $\begin{array}{l}0.0252 \\
(0.288)\end{array}$ & $\begin{array}{l}-0.0841 \\
(0.374)\end{array}$ & $\begin{array}{c}-3.474 * * * \\
(1.074)\end{array}$ & $\begin{array}{l}-1.376 * \\
(0.718)\end{array}$ \\
\hline GDP per capita & $\begin{array}{l}0.410^{*} \\
(0.238)\end{array}$ & $\begin{array}{c}2.725 * * * \\
(0.946)\end{array}$ & $\begin{array}{c}1.309 * * * \\
(0.319)\end{array}$ & $\begin{array}{c}0.625 \\
(0.426)\end{array}$ & $\begin{array}{l}-1.233 \\
(0.873)\end{array}$ & $\begin{array}{l}-1.153 \\
(0.828)\end{array}$ \\
\hline Observations & 260 & 255 & 207 & 225 & 193 & 202 \\
\hline R-squared & 0.486 & 0.862 & 0.936 & 0.124 & 0.220 & 0.118 \\
\hline
\end{tabular}

Note. Fixed-effects OLS estimation. The Hausman test's null hypothesis is rejected; the difference between random-effects estimates and fixed-effects estimates is systematic, and we should use the fixed-effects estimates. Year dummies and constant terms are not reported. $* * * \mathrm{p}<0.01, * * \mathrm{p}<0.05, *$ $\mathrm{p}<0.1$. 
Table 7. Testing the validity of our instruments "OLS estimations"

\begin{tabular}{|c|c|c|c|c|c|c|}
\hline \multirow{2}{*}{ VARIABLES } & \multicolumn{2}{|c|}{ Access } & \multirow[b]{2}{*}{$\begin{array}{c}\text { Productivity } \\
\text { Total } \\
\text { number of } \\
\text { Lines per } \\
\text { employee (in } \\
\text { log) }\end{array}$} & \multicolumn{3}{|c|}{ Affordability } \\
\hline & $\begin{array}{c}\text { Fixed per } \\
\quad 100 \\
\text { inhabitants } \\
\text { (in log) }\end{array}$ & $\begin{array}{l}\text { Mobile per } \\
100 \\
\text { inhabitants } \\
\quad \text { (in log) }\end{array}$ & & $\begin{array}{c}\text { Monthly } \\
\text { subscription } \\
\text { for } \\
\text { residential } \\
\text { telephone } \\
\text { service }\end{array}$ & $\begin{array}{c}\text { Price of 3- } \\
\text { minute fixed } \\
\text { local call } \\
\text { (off-peak } \\
\text { rate) (in log) }\end{array}$ & 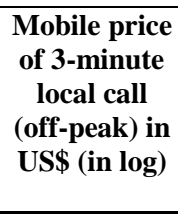 \\
\hline \multirow[t]{2}{*}{ Polity IV indicator } & 0.150 & 1.256 & -1.578 & -0.562 & 0.641 & $1.019 *$ \\
\hline & $(0.455)$ & $(1.432)$ & (1.043) & $(0.517)$ & $(0.533)$ & $(0.603)$ \\
\hline \multirow[t]{2}{*}{ Population density } & 0.0306 & 0.0165 & -0.0238 & -0.0233 & -0.125 & 0.0897 \\
\hline & $(0.0806)$ & $(0.150)$ & $(0.0395)$ & $(0.133)$ & $(0.116)$ & $(0.0801)$ \\
\hline \multirow[t]{2}{*}{ GDP per capita } & $0.655 * * *$ & $1.046 * * *$ & 0.0592 & $0.283 * *$ & $0.341 *$ & 0.0588 \\
\hline & $(0.0913)$ & $(0.167)$ & $(0.0769)$ & $(0.141)$ & $(0.193)$ & $(0.0955)$ \\
\hline Observations & 250 & 245 & 202 & 215 & 183 & 193 \\
\hline Number of country & 17 & 17 & 16 & 16 & 14 & 17 \\
\hline \multirow[t]{2}{*}{ Independence year } & $-0.0268 * * *$ & -0.0116 & -0.0189 & 0.00316 & 0.0158 & 0.00160 \\
\hline & $(0.00691)$ & $(0.0114)$ & $(0.0131)$ & $(0.0277)$ & $(0.0144)$ & $(0.00899)$ \\
\hline \multirow[t]{2}{*}{ Population density } & -0.00971 & $0.209^{*}$ & 0.0180 & 0.0353 & $-0.217 *$ & 0.118 \\
\hline & $(0.0863)$ & $(0.112)$ & $(0.0843)$ & $(0.146)$ & $(0.120)$ & $(0.0851)$ \\
\hline \multirow[t]{2}{*}{ GDP per capita } & $0.740^{* * *}$ & $0.941 * * *$ & $0.242^{* *}$ & $0.276^{* *}$ & $0.399 * *$ & -0.0472 \\
\hline & $(0.0924)$ & $(0.127)$ & $(0.117)$ & $(0.137)$ & $(0.185)$ & $(0.106)$ \\
\hline Observations & 228 & 223 & 178 & 194 & 163 & 174 \\
\hline Number of country & 15 & 15 & 15 & 14 & 12 & 15 \\
\hline \multirow[t]{2}{*}{ Civil law } & 0.327 & -0.0138 & 0.0439 & 0.535 & 0.0934 & $0.371 * *$ \\
\hline & $(0.200)$ & $(0.226)$ & $(0.230)$ & $(0.393)$ & $(0.438)$ & $(0.186)$ \\
\hline \multirow[t]{2}{*}{ Population density } & 0.0708 & $0.193^{* * *}$ & 0.00829 & -0.0410 & -0.0986 & 0.0540 \\
\hline & $(0.0572)$ & $(0.0744)$ & $(0.0668)$ & $(0.100)$ & $(0.114)$ & $(0.0498)$ \\
\hline \multirow[t]{2}{*}{ GDP per capita } & $0.630 * * *$ & $0.926 * * *$ & $0.196 * *$ & $0.327 * * *$ & 0.278 & -0.00710 \\
\hline & $(0.0921)$ & $(0.102)$ & $(0.0959)$ & $(0.112)$ & $(0.175)$ & $(0.0799)$ \\
\hline Observations & 260 & 255 & 207 & 225 & 193 & 202 \\
\hline Number of country & 17 & 17 & 17 & 16 & 14 & 17 \\
\hline \multirow[t]{2}{*}{$\begin{array}{l}\text { Total natural resources rents } \\
\text { of }(\% \text { of GDP })\end{array}$} & 0.00120 & -0.00653 & -0.000763 & -0.00684 & -0.0144 & -0.0105 \\
\hline & $(0.00448)$ & $(0.0104)$ & $(0.00921)$ & $(0.00968)$ & $(0.0114)$ & $(0.0133)$ \\
\hline \multirow[t]{2}{*}{ Population density } & 0.0418 & 0.161 & 0.00900 & -0.0623 & -0.174 & 0.00688 \\
\hline & $(0.0880)$ & $(0.108)$ & $(0.0750)$ & $(0.135)$ & $(0.119)$ & $(0.0982)$ \\
\hline \multirow[t]{2}{*}{ GDP per capita } & $0.641 * * *$ & $0.972 * * *$ & $0.189^{* *}$ & $0.370^{* * *}$ & $0.364 * *$ & 0.0721 \\
\hline & $(0.0893)$ & $(0.125)$ & $(0.0818)$ & $(0.134)$ & $(0.169)$ & $(0.165)$ \\
\hline Observations & 260 & 255 & 207 & 225 & 193 & 202 \\
\hline Number of country & 17 & 17 & 17 & 16 & 14 & 17 \\
\hline
\end{tabular}


Table 8. First-stage estimation

Parameters estimates for reform variables using OLS estimation

\begin{tabular}{|c|c|c|c|c|}
\hline Variables & $\begin{array}{l}\text { Establishment } \\
\text { of an IRA }\end{array}$ & $\begin{array}{l}\text { Privatization of } \\
\text { the incumbent } \\
\text { operator }\end{array}$ & $\begin{array}{l}\text { Competition } \\
\text { index }\end{array}$ & $\begin{array}{c}\text { Fixed } \\
\text { Competition }\end{array}$ \\
\hline \multirow[t]{2}{*}{ Polity IV indicator } & -0.213 & $-1.538 * * *$ & $-0.645^{*}$ & $-0.359 * *$ \\
\hline & $(0.187)$ & $(0.140)$ & $(0.341)$ & $(0.156)$ \\
\hline \multirow[t]{2}{*}{ Civil law } & --- & $-0.214 * * *$ & $-0.163 *$ & $-0.0994 * *$ \\
\hline & --- & $(0.0683)$ & $(0.0923)$ & $(0.0497)$ \\
\hline \multirow[t]{2}{*}{$\begin{array}{l}\text { Total natural resources rents of }(\% \text { of } \\
\text { GDP) }\end{array}$} & $-0.0144 * * *$ & $-0.0186^{* * *}$ & $-0.00616^{*}$ & $-0.00601 * * *$ \\
\hline & $(0.00187)$ & $(0.00243)$ & $(0.00367)$ & $(0.00211)$ \\
\hline \multirow[t]{2}{*}{ Independence year } & $-0.00763 * * *$ & --- & --- & --- \\
\hline & $(0.00197)$ & --- & --- & --- \\
\hline \multirow[t]{2}{*}{ Population density in log } & -0.00728 & -0.00574 & 0.0495 & -0.00344 \\
\hline & $(0.0248)$ & $(0.0217)$ & $(0.0314)$ & $(0.0167)$ \\
\hline \multirow[t]{2}{*}{ GDP per capita in constant US\$2000 in log } & $0.0598 * *$ & $0.0967 * * *$ & -0.0479 & 0.00743 \\
\hline & $(0.0265)$ & $(0.0268)$ & $(0.0410)$ & $(0.0170)$ \\
\hline \multirow[t]{2}{*}{ Constant } & $15.03 * * *$ & 0.222 & 0.529 & 0.184 \\
\hline & (3.838) & $(0.221)$ & $(0.329)$ & $(0.147)$ \\
\hline Observations & 218 & 250 & 250 & 250 \\
\hline R-squared & 0.396 & 0.450 & 0.426 & 0.303 \\
\hline F-value & 18.24 & 18.93 & 12.78 & 3.02 \\
\hline Prob $>$ F & 0.000 & 0.000 & 0.000 & 0.000 \\
\hline
\end{tabular}

Note. Robust standard errors in parentheses, including year dummies (not reported). Our results are robust when we exclude the control variables (population density and GDP per capita) from the estimation.

$* * * \mathrm{p}<0.01, * * \mathrm{p}<0.05, * \mathrm{p}<0.1$. 
Table 9. IV-2SLS estimation of the separate effects of each reform variable

\begin{tabular}{|c|c|c|c|c|c|c|}
\hline \multirow[b]{2}{*}{ VARIABLES } & \multicolumn{2}{|c|}{ ACCESS } & \multirow{2}{*}{$\begin{array}{c}\text { PRODUCTIVIT } \\
\text { Y } \\
\text { Total number of } \\
\text { Lines per } \\
\text { employee (in log) }\end{array}$} & \multicolumn{3}{|c|}{ AFFORDABILITY } \\
\hline & $\begin{array}{c}\text { Fixed per } 100 \\
\text { inhabitants (in } \\
\log )\end{array}$ & $\begin{array}{l}\text { Mobile per } \\
\quad 100 \\
\text { inhabitants } \\
\quad \text { (in log) }\end{array}$ & & $\begin{array}{c}\text { Monthly } \\
\text { subscription } \\
\text { for } \\
\text { residential } \\
\text { telephone } \\
\text { service } \\
\end{array}$ & $\begin{array}{c}\text { Price of 3- } \\
\text { minute fixed } \\
\text { local call (off- } \\
\text { peak) (in log) }\end{array}$ & $\begin{array}{l}\text { Mobile price } \\
\text { of 3-minute } \\
\text { local call (off- } \\
\text { peak) (in log) }\end{array}$ \\
\hline IRA establishment & $\begin{array}{c}0.600 * * * \\
(0.129)\end{array}$ & $\begin{array}{c}0.529 * \\
(0.275)\end{array}$ & $\begin{array}{c}1.124 * * * \\
(0.224)\end{array}$ & $\begin{array}{c}1.278 * * * \\
(0.290)\end{array}$ & $\begin{array}{l}0.0631 \\
(0.300)\end{array}$ & $\begin{array}{c}0.113 \\
(0.219)\end{array}$ \\
\hline Population density & $\begin{array}{c}0.120 * * * \\
(0.0346)\end{array}$ & $\begin{array}{c}0.225 * * * \\
(0.0679)\end{array}$ & $\begin{array}{l}0.00284 \\
(0.0538)\end{array}$ & $\begin{array}{c}-0.0309 \\
(0.0499)\end{array}$ & $\begin{array}{c}-0.161 * * \\
(0.0713)\end{array}$ & $\begin{array}{c}0.191 * * * \\
(0.0499)\end{array}$ \\
\hline GDP per capita & $\begin{array}{c}0.624 * * * \\
(0.0345)\end{array}$ & $\begin{array}{c}0.863 * * * \\
(0.0583)\end{array}$ & $\begin{array}{c}0.197 * * * \\
(0.0393)\end{array}$ & $\begin{array}{c}0.241 * * * \\
(0.0491)\end{array}$ & $\begin{array}{c}0.368 * * * \\
(0.0800)\end{array}$ & $\begin{array}{c}-0.0876^{*} \\
(0.0484)\end{array}$ \\
\hline Observations & 218 & 213 & 173 & 184 & 153 & 165 \\
\hline
\end{tabular}

Note. Robust standard errors are in parentheses. Variables used as instruments are "The Polity IV democracy indicator", "total natural resources rents (\% of GDP)" and "Independence year". Year dummies and constant terms are not reported. $* * * \mathrm{p}<0.01, * * \mathrm{p}<0.05, * \mathrm{p}<0.1$

\begin{tabular}{|c|c|c|c|c|c|c|}
\hline Privatization & $\begin{array}{c}-0.247 * * \\
(0.115)\end{array}$ & $\begin{array}{c}0.516^{* *} \\
(0.255)\end{array}$ & $\begin{array}{c}0.913 * * * \\
(0.203)\end{array}$ & $\begin{array}{c}0.573 * * * \\
(0.211)\end{array}$ & $\begin{array}{c}0.655^{* * *} * \\
(0.220)\end{array}$ & $\begin{array}{c}-0.176 \\
(0.189)\end{array}$ \\
\hline \multirow[t]{2}{*}{ Population density } & $0.173 * * *$ & $0.159 * * *$ & $-0.0909 * * *$ & $-0.154 * * *$ & $-0.113 * * *$ & $0.134 * * *$ \\
\hline & $(0.0185)$ & $(0.0465)$ & $(0.0306)$ & $(0.0354)$ & $(0.0435)$ & $(0.0385)$ \\
\hline \multirow[t]{2}{*}{ GDP per capita } & $0.606^{* * * *}$ & $0.844 * * *$ & $0.0983^{* * *}$ & $0.235^{* * *}$ & $0.209 * * *$ & -0.0349 \\
\hline & $(0.0277)$ & $(0.0531)$ & $(0.0355)$ & $(0.0461)$ & $(0.0537)$ & $(0.0398)$ \\
\hline Observations & 250 & 245 & 202 & 215 & 183 & 193 \\
\hline \multicolumn{7}{|c|}{$\begin{array}{l}\text { Note. Robust standard errors are in parentheses. Variables used as instruments are "The Polity IV democracy indicator", "Legal origir } \\
\text { dummy variable" and "total natural resources rents ( } \% \text { of GDP)". Year dummies and constant terms are not reported. } \\
* * * p<0.01, * * p<0.05, * \mathrm{p}<0.1 \text {. }\end{array}$} \\
\hline Competition index & $\begin{array}{c}-0.978^{*} \\
(0.523)\end{array}$ & $\begin{array}{l}1.117 * * \\
(0.496)\end{array}$ & $\begin{array}{l}-0.579 \\
(0.622)\end{array}$ & $\begin{array}{l}0.0321 \\
(0.382)\end{array}$ & $\begin{array}{c}-0.0390 \\
(0.478)\end{array}$ & $\begin{array}{c}-1.305^{* *} \\
(0.542)\end{array}$ \\
\hline \multirow[t]{2}{*}{ Population density } & $0.222 * * *$ & $0.117 * *$ & 0.00965 & $-0.136^{* * *}$ & $-0.0837 * *$ & $0.194 * * *$ \\
\hline & $(0.0444)$ & $(0.0576)$ & $(0.0647)$ & $(0.0325)$ & $(0.0425)$ & $(0.0530)$ \\
\hline \multirow[t]{2}{*}{ GDP per capita } & $0.546^{* * * *}$ & $0.932 * * *$ & $0.153 * * *$ & $0.288 * * *$ & $0.264 * * *$ & $-0.0995 *$ \\
\hline & $(0.0420)$ & $(0.0540)$ & $(0.0332)$ & $(0.0427)$ & $(0.0567)$ & $(0.0553)$ \\
\hline Observations & 250 & 245 & 202 & 215 & 183 & 193 \\
\hline \multicolumn{7}{|c|}{$\begin{array}{l}\text { Note. Robust standard errors are in parentheses. Variables used as instruments are "The Polity IV democracy indicator", "Legal origin } \\
\text { dummy variable" and "total natural resources rents (\% of GDP)". Year dummies and constant terms are not reported. } \\
* * * \mathrm{p}<0.01, * * \mathrm{p}<0.05, * \mathrm{p}<0.1\end{array}$} \\
\hline \multirow[t]{2}{*}{ Fixed competition } & $-1.517 * *$ & $2.040 * *$ & 0.596 & $2.540 * *$ & $2.371 *$ & -1.041 \\
\hline & $(0.674)$ & $(0.870)$ & $(0.736)$ & $(1.215)$ & $(1.278)$ & $(0.762)$ \\
\hline \multirow[t]{2}{*}{ Population density } & $0.187 * * *$ & $0.151 * *$ & -0.0627 & $-0.195 * * *$ & $-0.138^{*}$ & $0.145 * * *$ \\
\hline & $(0.0245)$ & $(0.0612)$ & $(0.0402)$ & $(0.0644)$ & $(0.0764)$ & $(0.0386)$ \\
\hline \multirow[t]{2}{*}{ GDP per capita } & $0.573 * * *$ & $0.904 * * *$ & $0.184 * * *$ & $0.306^{* * *}$ & $0.193 * * *$ & -0.0606 \\
\hline & $(0.0294)$ & $(0.0515)$ & $(0.0256)$ & $(0.0536)$ & $(0.0748)$ & $(0.0416)$ \\
\hline Observations & 250 & 245 & 202 & 215 & 183 & 193 \\
\hline \multicolumn{7}{|c|}{$\begin{array}{l}\text { Note. Robust standard errors are in parentheses. Variables used as instruments are "The Polity IV democracy indicator", "Legal origin } \\
\text { dummy variable" and "total natural resources rents (\% of GDP)". Year dummies and constant terms are not reported. } \\
* * * \mathrm{p}<0.01, * * \mathrm{p}<0.05, * \mathrm{p}<0.1 \text {. }\end{array}$} \\
\hline \multirow[t]{2}{*}{ Mobile competition } & -0.314 & 0.664 & -4.751 & $-2.113 * *$ & $-2.546^{*}$ & $-1.974 * *$ \\
\hline & $(0.696)$ & $(0.973)$ & $(5.890)$ & $(0.846)$ & $(1.510)$ & $(0.970)$ \\
\hline \multirow[t]{2}{*}{ Population density } & $0.170 * * *$ & $0.167 * * *$ & 0.0890 & $-0.168 * * *$ & $-0.132 *$ & $0.149 * *$ \\
\hline & $(0.0265)$ & $(0.0496)$ & $(0.187)$ & $(0.0534)$ & $(0.0753)$ & $(0.0592)$ \\
\hline \multirow[t]{2}{*}{ GDP per capita } & $0.582 * * *$ & $0.897 * * *$ & 0.101 & $0.296 * * *$ & $0.283 * * *$ & -0.0789 \\
\hline & $(0.0305)$ & $(0.0485)$ & $(0.126)$ & $(0.0584)$ & $(0.0742)$ & $(0.0611)$ \\
\hline Observations & 250 & 245 & 202 & 215 & 183 & 193 \\
\hline
\end{tabular}


Table 10. IV-2SLS estimation of the effect of the interactions of different reforms

\begin{tabular}{|c|c|c|c|c|c|c|}
\hline & \multicolumn{2}{|c|}{ ACCESS } & \multirow[b]{2}{*}{$\begin{array}{c}\text { PRODUCTIVITY } \\
\text { Total number of } \\
\text { Lines per employee } \\
\text { (in log) }\end{array}$} & \multicolumn{3}{|c|}{ AFFORDABILITY } \\
\hline VARIABLES & $\begin{array}{l}\text { Fixed per } 100 \\
\text { inhabitants (in } \\
\log )\end{array}$ & $\begin{array}{l}\text { Mobile per } 100 \\
\text { inhabitants (in } \\
\text { log) }\end{array}$ & & $\begin{array}{c}\text { Monthly } \\
\text { subscription } \\
\text { for } \\
\text { residential } \\
\text { telephone } \\
\text { service }\end{array}$ & $\begin{array}{c}\text { Price of 3- } \\
\text { minute fixed } \\
\text { local call (off- } \\
\text { peak rate) (in } \\
\text { log) }\end{array}$ & $\begin{array}{l}\text { Mobile price } \\
\text { of 3-minute } \\
\text { local call (off- } \\
\text { peak) in US\$ } \\
\text { (in log) }\end{array}$ \\
\hline IRA establishment & $\begin{array}{c}0.259 \\
(0.613)\end{array}$ & $\begin{array}{c}0.201 \\
(0.500)\end{array}$ & $\begin{array}{c}0.151 \\
(0.843)\end{array}$ & $\begin{array}{c}2.254 * * * \\
(0.703)\end{array}$ & $\begin{array}{c}-1.177 * * \\
(0.532)\end{array}$ & $\begin{array}{l}1.032 * \\
(0.587)\end{array}$ \\
\hline Privatization & $\begin{array}{c}-5.785^{* * * *} \\
(1.992)\end{array}$ & $\begin{array}{l}-1.268 \\
(1.823)\end{array}$ & $\begin{array}{l}-2.824 \\
(2.301)\end{array}$ & $\begin{array}{l}5.972 * * \\
(2.545)\end{array}$ & $\begin{array}{l}-4.655^{*} \\
(2.742)\end{array}$ & $\begin{array}{l}4.024 * \\
(2.098)\end{array}$ \\
\hline IRA $*$ Privatization & $\begin{array}{l}6.318 * * \\
(2.488)\end{array}$ & $\begin{array}{c}1.878 \\
(2.292)\end{array}$ & $\begin{array}{c}4.544 \\
(3.483)\end{array}$ & $\begin{array}{c}-7.597 * * \\
(3.187)\end{array}$ & $\begin{array}{l}6.332 * \\
(3.301)\end{array}$ & $\begin{array}{c}-5.577 * * \\
(2.616)\end{array}$ \\
\hline Population density & $\begin{array}{c}0.204 \\
(0.136)\end{array}$ & $\begin{array}{l}0.241 * * \\
(0.0992)\end{array}$ & $\begin{array}{c}0.00492 \\
(0.125)\end{array}$ & $\begin{array}{c}0.00116 \\
(0.158)\end{array}$ & $\begin{array}{c}-0.0801 \\
(0.164)\end{array}$ & $\begin{array}{c}0.166 \\
(0.137)\end{array}$ \\
\hline GDP per capita & $\begin{array}{c}1.128 * * * \\
(0.147)\end{array}$ & $\begin{array}{c}0.973 * * * \\
(0.159)\end{array}$ & $\begin{array}{l}0.482 * * \\
(0.235)\end{array}$ & $\begin{array}{l}-0.348 \\
(0.295)\end{array}$ & $\begin{array}{c}0.684 * * * \\
(0.204)\end{array}$ & $\begin{array}{c}-0.494 * * \\
(0.234)\end{array}$ \\
\hline Observations & 218 & 213 & 173 & 184 & 153 & 165 \\
\hline
\end{tabular}

Note. Robust standard errors in parentheses. Variables used as instruments are "The Polity IV democracy indicator", "Legal origin dummy variable",

"total natural resources rents (\% of GDP)" and "independence year from colonization". Year dummies and constant terms are not reported.

$* * * \mathrm{p}<0.01, * * \mathrm{p}<0.05, * \mathrm{p}<0.1$. (...) means are not reported.

\begin{tabular}{|c|c|c|c|c|c|c|}
\hline Privatization & $\begin{array}{c}2.550 \\
(3.353)\end{array}$ & $\begin{array}{c}-0.395 \\
(0.953)\end{array}$ & $\begin{array}{l}-6.180 \\
(8.842)\end{array}$ & $\begin{array}{c}4.389 \\
(14.50)\end{array}$ & $\begin{array}{c}-2.081 * * \\
(0.812)\end{array}$ & $\begin{array}{c}3.043 \\
(4.334)\end{array}$ \\
\hline Fixed competition & $\begin{array}{c}-15.18 \\
(14.45)\end{array}$ & $\begin{array}{l}-5.786 \\
(6.076)\end{array}$ & $\begin{array}{c}-38.90 \\
(50.22)\end{array}$ & $\begin{array}{c}-40.12 \\
(115.2)\end{array}$ & $\begin{array}{c}-17.26 * \\
(9.382)\end{array}$ & $\begin{array}{c}14.71 \\
(28.26)\end{array}$ \\
\hline $\begin{array}{l}\text { Fixed Competition * } \\
\text { Privatization }\end{array}$ & 2.861 & 6.169 & 48.75 & 14.80 & $18.86^{* *}$ & -20.28 \\
\hline & $(14.90)$ & $(5.840)$ & $(63.67)$ & (109.6) & $(9.424)$ & $(32.19)$ \\
\hline Population density & $\begin{array}{c}0.190 \\
(0.199)\end{array}$ & $\begin{array}{l}0.191 * * \\
(0.0780)\end{array}$ & $\begin{array}{c}-0.749 \\
(1.106)\end{array}$ & $\begin{array}{l}-0.0917 \\
(2.471)\end{array}$ & $\begin{array}{c}-0.852 * * * \\
(0.240)\end{array}$ & $\begin{array}{c}0.527 \\
(0.541)\end{array}$ \\
\hline GDP per capita & $\begin{array}{c}0.287 \\
(0.321) \\
\end{array}$ & $\begin{array}{c}0.869 * * * \\
(0.117)\end{array}$ & $\begin{array}{c}0.945 \\
(1.160) \\
\end{array}$ & $\begin{array}{c}-0.208 \\
(2.019)\end{array}$ & $\begin{array}{c}1.003 * * * \\
(0.259)\end{array}$ & $\begin{array}{c}-0.471 \\
(0.537) \\
\end{array}$ \\
\hline Observations & 218 & 213 & 173 & 184 & 153 & 165 \\
\hline \multicolumn{7}{|c|}{$\begin{array}{l}\text { Note. Robust standard errors are in parentheses. Variables used as instruments are "The Polity IV democracy indicator", "Legal origin dummy } \\
\text { variable", "total natural resources rents (\% of GDP)" and "independence year from colonization". Year dummies and constant terms are not reported. } \\
* * * \mathrm{p}<0.01, * * \mathrm{p}<0.05, * \mathrm{p}<0.1 .(\ldots) \text { means are not reported. }\end{array}$} \\
\hline IRA establishment & $\begin{array}{c}1.245 \\
(0.891)\end{array}$ & $\begin{array}{c}0.911 \\
(0.723)\end{array}$ & $\begin{array}{c}3.021 * * * \\
(1.132)\end{array}$ & $\begin{array}{c}0.337 \\
(0.461)\end{array}$ & $\begin{array}{c}-0.0794 \\
(0.500)\end{array}$ & $\begin{array}{c}0.636 \\
(0.799)\end{array}$ \\
\hline Competition Index & $\begin{array}{c}-0.538 \\
(0.779)\end{array}$ & $\begin{array}{c}1.327 \\
(0.900)\end{array}$ & $\begin{array}{c}1.125 \\
(0.820)\end{array}$ & $\begin{array}{c}-1.756^{* * *} * \\
(0.649)\end{array}$ & $\begin{array}{c}-3.048 * * * \\
(0.792)\end{array}$ & $\begin{array}{c}-1.381 * * * \\
(0.535)\end{array}$ \\
\hline IRA*Competition Index & $\begin{array}{c}-0.753 \\
(1.048)\end{array}$ & $\begin{array}{c}-0.750 \\
(0.977)\end{array}$ & $\begin{array}{l}-2.675^{*} \\
(1.581)\end{array}$ & $\begin{array}{l}1.807 * * \\
(0.814)\end{array}$ & $\begin{array}{l}2.057 * \\
(1.077)\end{array}$ & $\begin{array}{c}-0.0846 \\
(1.061)\end{array}$ \\
\hline Population density & $\begin{array}{c}0.177 * * * \\
(0.0683)\end{array}$ & $\begin{array}{c}0.143 \\
(0.0916)\end{array}$ & $\begin{array}{c}0.125 \\
(0.0951)\end{array}$ & $\begin{array}{l}-0.0345 \\
(0.0532)\end{array}$ & $\begin{array}{l}-0.166^{* *} \\
(0.0812)\end{array}$ & $\begin{array}{c}0.248 * * * \\
(0.0779)\end{array}$ \\
\hline GDP per capita & $\begin{array}{c}0.582 * * * \\
(0.0441)\end{array}$ & $\begin{array}{l}0.911 * * * \\
(0.0679)\end{array}$ & $\begin{array}{l}0.175 * * \\
(0.0717)\end{array}$ & $\begin{array}{c}0.237 * * * \\
(0.0525)\end{array}$ & $\begin{array}{c}0.276^{* * *} \\
(0.127)\end{array}$ & $\begin{array}{c}-0.107 \\
(0.0701)\end{array}$ \\
\hline Observations & 218 & 213 & 173 & 184 & 153 & 165 \\
\hline
\end{tabular}

Note. Robust standard errors are in parentheses. Variables used as instruments are "The Polity IV democracy indicator", "Legal origin dummy variable", "total natural resources rents (\% of GDP)" and "independence year from colonization". Year dummies and constant terms are not reported. $* * * \mathrm{p}<0.01, * * \mathrm{p}<0.05, * \mathrm{p}<0.1$. (...) means are not reported

\begin{tabular}{|c|c|c|c|c|c|c|}
\hline Three-way interaction & $\begin{array}{c}-0.378 * * * \\
(0.134)\end{array}$ & $\begin{array}{c}0.503 * * \\
(0.229)\end{array}$ & $\begin{array}{c}0.868 * * * \\
(0.172)\end{array}$ & $\begin{array}{c}0.635 * * * \\
(0.202)\end{array}$ & $\begin{array}{c}0.639 * * * \\
(0.240)\end{array}$ & $\begin{array}{l}-0.166 \\
(0.192)\end{array}$ \\
\hline Population density & $\begin{array}{c}0.195 * * * \\
(0.0283)\end{array}$ & $\begin{array}{c}0.206 * * * \\
(0.0709)\end{array}$ & $\begin{array}{l}-0.0910 \\
(0.0635)\end{array}$ & $\begin{array}{l}-0.109 * \\
(0.0648)\end{array}$ & $\begin{array}{l}-0.207 * * \\
(0.0804)\end{array}$ & $\begin{array}{c}0.209 * * * \\
(0.0537)\end{array}$ \\
\hline GDP per capita & $\begin{array}{c}0.574 * * * \\
(0.0265)\end{array}$ & $\begin{array}{c}0.854 * * * \\
(0.0550)\end{array}$ & $\begin{array}{c}0.179 * * * \\
(0.0367)\end{array}$ & $\begin{array}{c}0.247 * * * \\
(0.0497)\end{array}$ & $\begin{array}{c}0.316 * * * \\
(0.0864)\end{array}$ & $\begin{array}{c}-0.101 * * \\
(0.0479)\end{array}$ \\
\hline Observations & 218 & 213 & 173 & 184 & 153 & 165 \\
\hline
\end{tabular}

Note. Robust standard errors are in parentheses. Variables used as instruments are "The Polity IV democracy indicator", "Legal origin dummy variable", "total natural resources rents (\% of GDP)" and "independence year from colonization". Year dummies and constant terms are not reported.

$* * * \mathrm{p}<0.01, * * \mathrm{p}<0.05, * \mathrm{p}<0.1$. (..) means are not reported. 
Table 11. Dynamic IV-2SLS estimation "The separate effects of each reform variable"

\section{ACCESS}

\begin{tabular}{|c|c|c|}
\hline VARIABLES & $\begin{array}{l}\text { Fixed per } 100 \\
\text { inhabitants } \\
\text { (in log) }\end{array}$ & $\begin{array}{l}\text { Mobile per 100 } \\
\text { inhabitants (in } \\
\log \text { ) }\end{array}$ \\
\hline
\end{tabular}

PRODUCTIVITY

Total number of
Lines per
employee (in log)

\begin{tabular}{|c|c|c|c|c|c|c|}
\hline \multirow[b]{2}{*}{ IRA establishment } & & & & service & & \\
\hline & $\begin{array}{c}0.657 * * * \\
(0.136)\end{array}$ & $\begin{array}{c}0.564 * * \\
(0.272)\end{array}$ & $\begin{array}{c}1.212 * * * \\
(0.246)\end{array}$ & $\begin{array}{c}1.241 * * * \\
(0.310)\end{array}$ & $\begin{array}{l}0.0850 \\
(0.295)\end{array}$ & $\begin{array}{l}0.0492 \\
(0.221)\end{array}$ \\
\hline \multirow[t]{2}{*}{ Population density } & $0.108 * * *$ & $0.219 * * *$ & -0.00567 & -0.0235 & $-0.156^{* *}$ & $0.193 * * *$ \\
\hline & $(0.0371)$ & $(0.0713)$ & $(0.0606)$ & $(0.0514)$ & $(0.0686)$ & $(0.0504)$ \\
\hline \multirow[t]{2}{*}{ GDP per capita } & $0.619 * * *$ & $0.833 * * *$ & $0.203 * * *$ & $0.249 * * *$ & $0.350 * * *$ & $-0.0901 *$ \\
\hline & $(0.0361)$ & $(0.0597)$ & $(0.0425)$ & $(0.0493)$ & $(0.0766)$ & $(0.0494)$ \\
\hline Observations & 205 & 203 & 159 & 172 & 149 & 158 \\
\hline
\end{tabular}

Note. Robust standard errors in parentheses. Variables used as instruments are "The Polity IV democracy indicator", "total natural resources rents (\% of GDP)" and "Independence year". Year dummies and constant terms are not reported.

$* * * \mathrm{p}<0.01, * * \mathrm{p}<0.05, * \mathrm{p}<0.1$.

\begin{tabular}{|c|c|c|c|c|c|c|}
\hline Privatization & $\begin{array}{c}-0.255^{* *} * \\
(0.120)\end{array}$ & $\begin{array}{c}0.327 \\
(0.262)\end{array}$ & $\begin{array}{c}1.046 * * * \\
(0.231)\end{array}$ & $\begin{array}{c}0.592 * * * \\
(0.224)\end{array}$ & $\begin{array}{c}0.726 * * * \\
(0.228)\end{array}$ & $\begin{array}{l}-0.137 \\
(0.192)\end{array}$ \\
\hline \multirow[t]{2}{*}{ Population density } & $0.170 * * *$ & $0.152 * * *$ & $-0.113^{* * *}$ & $-0.156^{* * *}$ & $-0.133 * * *$ & $0.118 * * *$ \\
\hline & $(0.0196)$ & $(0.0493)$ & $(0.0331)$ & $(0.0377)$ & $(0.0468)$ & $(0.0387)$ \\
\hline \multirow[t]{2}{*}{ GDP per capita } & $0.596 * * *$ & $0.833 * * *$ & $0.0804 * *$ & $0.240 * * *$ & $0.203 * * *$ & -0.0325 \\
\hline & $(0.0279)$ & $(0.0521)$ & $(0.0401)$ & $(0.0479)$ & $(0.0565)$ & $(0.0397)$ \\
\hline Observations & 235 & 233 & 186 & 201 & 177 & 184 \\
\hline \multicolumn{7}{|c|}{$\begin{array}{l}\text { Note. Robust standard errors in parentheses. Variables used as instruments are "The Polity IV democracy indicator", "Legal origin dummy variable" } \\
\text { and "total natural resources rents }(\% \text { of GDP)". Year dummies and constant terms are not reported. } \\
* * * \mathrm{p}<0.01, * * \mathrm{p}<0.05, * \mathrm{p}<0.1 \text {. }\end{array}$} \\
\hline \multirow[t]{2}{*}{ Competition index } & $-1.200 *$ & 0.805 & -0.136 & -0.140 & -0.0152 & $-1.950 *$ \\
\hline & $(0.720)$ & $(0.623)$ & $(0.454)$ & $(0.408)$ & $(0.634)$ & $(1.092)$ \\
\hline \multirow[t]{2}{*}{ Population density } & $0.247 * * *$ & $0.109 *$ & -0.0408 & $-0.125^{* * *}$ & $-0.0914 *$ & $0.232 * * *$ \\
\hline & $(0.0648)$ & $(0.0659)$ & $(0.0509)$ & $(0.0371)$ & $(0.0482)$ & $(0.0874)$ \\
\hline \multirow[t]{2}{*}{ GDP per capita } & $0.518 * * *$ & $0.897 * * *$ & $0.168 * * *$ & $0.290 * * *$ & $0.267 * * *$ & -0.136 \\
\hline & $(0.0552)$ & $(0.0560)$ & $(0.0263)$ & $(0.0443)$ & $(0.0594)$ & $(0.0851)$ \\
\hline Observations & 235 & 233 & 186 & 201 & 177 & 184 \\
\hline
\end{tabular}

Note. Robust standard errors in parentheses. Variables used as instruments are "The Polity IV democracy indicator", "Legal origin dummy variable" and "total natural resources rents (\% of GDP)". Year dummies and constant terms are not reported..

$* * * \mathrm{p}<0.01, * * \mathrm{p}<0.05, * \mathrm{p}<0.1$

\begin{tabular}{|c|c|c|c|c|c|c|}
\hline Fixed competition & $\begin{array}{c}-1.766^{* *} \\
(0.875)\end{array}$ & $\begin{array}{c}1.603 \\
(1.004)\end{array}$ & $\begin{array}{c}0.656 \\
(0.672)\end{array}$ & $\begin{array}{l}3.761 * * \\
(1.906)\end{array}$ & $\begin{array}{l}4.951 * \\
(2.867)\end{array}$ & $\begin{array}{l}-1.420 \\
(1.072)\end{array}$ \\
\hline Population density & $\begin{array}{c}0.196 * * * \\
(0.0297)\end{array}$ & $\begin{array}{l}0.134 * * \\
(0.0619)\end{array}$ & $\begin{array}{c}-0.0789 * * \\
(0.0382)\end{array}$ & $\begin{array}{c}-0.247 * * * \\
(0.0917)\end{array}$ & $\begin{array}{c}-0.240 * \\
(0.127)\end{array}$ & $\begin{array}{c}0.135 * * * \\
(0.0402)\end{array}$ \\
\hline GDP per capita & $\begin{array}{c}0.554 * * * \\
(0.0311)\end{array}$ & $\begin{array}{c}0.878 * * * \\
(0.0503)\end{array}$ & $\begin{array}{c}0.177 * * * \\
(0.0279)\end{array}$ & $\begin{array}{c}0.331 * * * \\
(0.0670)\end{array}$ & $\begin{array}{l}0.192 * \\
(0.106)\end{array}$ & $\begin{array}{c}-0.0585 \\
(0.0451)\end{array}$ \\
\hline Observations & 235 & 233 & 186 & 201 & 177 & 184 \\
\hline
\end{tabular}

Note. Robust standard errors in parentheses. Variables used as instruments are "The Polity IV democracy indicator", "Legal origin dummy variable" and "total natural resources rents (\% of GDP)". Year dummies and constant terms are not reported.

$* * * \mathrm{p}<0.01, * * \mathrm{p}<0.05, * \mathrm{p}<0.1$.

\begin{tabular}{|c|c|c|c|c|c|c|}
\hline \multirow[t]{2}{*}{ Mobile competition } & -0.0449 & -0.0286 & -1.915 & $-2.819 * *$ & $-2.870^{*}$ & -1.294 \\
\hline & $(0.765)$ & $(1.344)$ & $(3.057)$ & $(1.214)$ & $(1.718)$ & $(1.096)$ \\
\hline \multirow[t]{2}{*}{ Population density } & $0.156 * * *$ & $0.173 * * *$ & 0.00483 & $-0.156 * *$ & -0.123 & $0.138 * *$ \\
\hline & $(0.0323)$ & $(0.0660)$ & $(0.103)$ & $(0.0697)$ & $(0.0760)$ & $(0.0561)$ \\
\hline \multirow[t]{2}{*}{ GDP per capita } & $0.576 * * *$ & $0.856 * * *$ & $0.146 * * *$ & $0.296 * * *$ & $0.269 * * *$ & -0.0695 \\
\hline & $(0.0308)$ & $(0.0544)$ & $(0.0522)$ & $(0.0720)$ & $(0.0745)$ & $(0.0541)$ \\
\hline Observations & 235 & 233 & 186 & 201 & 177 & 184 \\
\hline
\end{tabular}

\begin{tabular}{lcccc} 
Observations & 235 & 233 & 186 & 201 \\
\hline Note. Robust standard errors in parentheses. Variables used as instruments are "The Polity IV democracy indicator", "Legal origin dummy variable"
\end{tabular} and "total natural resources rents (\% of GDP)". Year dummies and constant terms are not reported.

$* * * \mathrm{p}<0.01, * * \mathrm{p}<0.05, * \mathrm{p}<0.1$. 
Table 12. Dynamic IV-2SLS estimation of the effect of the interactions of different reforms

\begin{tabular}{|c|c|c|c|c|c|c|}
\hline \multirow[b]{2}{*}{ VARIABLES } & \multicolumn{2}{|c|}{ ACCESS } & \multirow[b]{2}{*}{$\begin{array}{c}\text { PRODUCTIVITY } \\
\text { Total number of } \\
\text { Lines per employee } \\
\text { (in log) }\end{array}$} & \multicolumn{3}{|c|}{ AFFORDABILITY } \\
\hline & $\begin{array}{c}\text { Fixed per } 100 \\
\text { inhabitants (in } \\
\log )\end{array}$ & $\begin{array}{l}\text { Mobile per 100 } \\
\text { inhabitants (in } \\
\log )\end{array}$ & & $\begin{array}{c}\text { Monthly } \\
\text { subscription } \\
\text { for } \\
\text { residential } \\
\text { telephone } \\
\text { service } \\
\end{array}$ & $\begin{array}{c}\text { Price of 3- } \\
\text { minute fixed } \\
\text { local call (off- } \\
\text { peak rate) (in } \\
\text { log) }\end{array}$ & $\begin{array}{l}\text { Mobile price } \\
\text { of 3-minute } \\
\text { local call (off- } \\
\text { peak) in US\$ } \\
\text { (in log) }\end{array}$ \\
\hline IRA establishment & $\begin{array}{c}0.310 \\
(0.633)\end{array}$ & $\begin{array}{c}0.369 \\
(0.563)\end{array}$ & $\begin{array}{c}0.300 \\
(0.872)\end{array}$ & $\begin{array}{c}2.544^{* * *} \\
(0.836)\end{array}$ & $\begin{array}{c}-1.464 * * \\
(0.597)\end{array}$ & $\begin{array}{c}0.973 \\
(0.737)\end{array}$ \\
\hline Privatization & $\begin{array}{c}-5.328 * * * \\
(1.947)\end{array}$ & $\begin{array}{l}-1.555 \\
(1.871)\end{array}$ & $\begin{array}{l}-2.458 \\
(2.247)\end{array}$ & $\begin{array}{c}6.058 * * \\
(2.547)\end{array}$ & $\begin{array}{c}-4.539 * * \\
(2.251)\end{array}$ & $\begin{array}{l}4.347 \\
(2.710)\end{array}$ \\
\hline IRA* Privatization & $\begin{array}{l}5.822 * * \\
(2.507)\end{array}$ & $\begin{array}{l}1.966 \\
(2.485)\end{array}$ & $\begin{array}{c}4.283 \\
(3.577)\end{array}$ & $\begin{array}{c}-7.947 * * \\
(3.269)\end{array}$ & $\begin{array}{l}6.550 * * \\
(2.837)\end{array}$ & $\begin{array}{l}-6.223^{*} \\
(3.649)\end{array}$ \\
\hline Population density & $\begin{array}{c}0.201 \\
(0.135)\end{array}$ & $\begin{array}{c}0.240 * * \\
(0.106)\end{array}$ & $\begin{array}{c}-0.00383 \\
(0.129)\end{array}$ & $\begin{array}{c}0.000155 \\
(0.169)\end{array}$ & $\begin{array}{l}-0.0746 \\
(0.182)\end{array}$ & $\begin{array}{l}0.166 \\
(0.162)\end{array}$ \\
\hline GDP per capita & $\begin{array}{c}1.106^{* * * *} \\
(0.150)\end{array}$ & $\begin{array}{c}0.974 * * * \\
(0.164) \\
\end{array}$ & $\begin{array}{l}0.474 * \\
(0.246) \\
\end{array}$ & $\begin{array}{l}-0.372 \\
(0.309) \\
\end{array}$ & $\begin{array}{c}0.770 * * * \\
(0.246)\end{array}$ & $\begin{array}{l}-0.553 * \\
(0.299)\end{array}$ \\
\hline Observations & 205 & 203 & 159 & 172 & 149 & 158 \\
\hline \multicolumn{7}{|c|}{$\begin{array}{l}\text { Note. Robust standard errors are in parentheses. Variables used as instruments are "The Polity IV democracy indicator", "Legal origin dummy variable", } \\
\text { "total natural resources rents }(\% \text { of GDP)" and "independence year from colonization". Year dummies and constant terms are not reported. } \\
* * * p<0.01, * * p<0.05, * p<0.1 \text {. (..) means are not reported. }\end{array}$} \\
\hline Privatization & $\begin{array}{c}2.868 \\
(4.858)\end{array}$ & $\begin{array}{l}-0.382 \\
(1.290)\end{array}$ & $\begin{array}{l}-2.208 \\
(2.267)\end{array}$ & $\begin{array}{c}0.788 \\
(11.90)\end{array}$ & $\begin{array}{c}-1.690^{* *} \\
(0.779)\end{array}$ & $\begin{array}{c}7.481 \\
(19.78)\end{array}$ \\
\hline Fixed competition & $\begin{array}{l}-19.08 \\
(18.14)\end{array}$ & $\begin{array}{l}-7.308 \\
(6.560)\end{array}$ & $\begin{array}{l}-17.04 \\
(13.81)\end{array}$ & $\begin{array}{l}-40.65 \\
(80.96)\end{array}$ & $\begin{array}{l}-14.26^{*} \\
(7.870)\end{array}$ & $\begin{array}{c}24.71 \\
(79.54)\end{array}$ \\
\hline $\begin{array}{l}\text { Fixed Competition * } \\
\text { Privatization }\end{array}$ & 3.174 & 6.434 & 20.27 & 22.98 & $15.96 * *$ & -44.42 \\
\hline & $(18.29)$ & $(6.749)$ & $(16.18)$ & $(84.33)$ & (7.958) & (120.8) \\
\hline Population density & $\begin{array}{l}0.190 \\
(0.256)\end{array}$ & $\begin{array}{l}0.201 * * \\
(0.0823)\end{array}$ & $\begin{array}{l}-0.346 \\
(0.294)\end{array}$ & $\begin{array}{l}-0.487 \\
(2.025)\end{array}$ & $\begin{array}{c}-0.741 * * * \\
(0.213)\end{array}$ & $\begin{array}{c}0.959 \\
(2.183)\end{array}$ \\
\hline GDP per capita & $\begin{array}{c}0.229 \\
(0.475) \\
\end{array}$ & $\begin{array}{c}0.821 * * * \\
(0.145)\end{array}$ & $\begin{array}{c}0.431 \\
(0.283)\end{array}$ & $\begin{array}{c}0.299 \\
(1.678)\end{array}$ & $\begin{array}{c}0.860 * * * \\
(0.225)\end{array}$ & $\begin{array}{l}-1.022 \\
(2.382)\end{array}$ \\
\hline Observations & 205 & 203 & 159 & 172 & 149 & 158 \\
\hline \multicolumn{7}{|c|}{$\begin{array}{l}\text { Note. Robust standard errors are in parentheses. Variables used as instruments are "The Polity IV democracy indicator", "Legal origin dummy variable", } \\
\text { "total natural resources rents }(\% \text { of GDP)" and "independence year from colonization". Year dummies and constant terms are not reported. } \\
* * * p<0.01, * * \mathrm{p}<0.05, * \mathrm{p}<0.1 \text {. (...) means are not reported. }\end{array}$} \\
\hline IRA establishment & $\begin{array}{c}1.555 \\
(1.075)\end{array}$ & $\begin{array}{c}1.458 \\
(1.138)\end{array}$ & $\begin{array}{c}3.038 * * * \\
(1.058)\end{array}$ & $\begin{array}{c}0.447 \\
(0.529)\end{array}$ & $\begin{array}{c}0.120 \\
(0.688)\end{array}$ & $\begin{array}{l}0.893 \\
(1.876)\end{array}$ \\
\hline Competition Index & $\begin{array}{l}-0.114 \\
(0.819)\end{array}$ & $\begin{array}{l}1.199 \\
(1.009)\end{array}$ & $\begin{array}{c}0.937 \\
(0.809)\end{array}$ & $\begin{array}{c}-2.157 * * * \\
(0.716)\end{array}$ & $\begin{array}{c}-3.592 * * * \\
(0.999)\end{array}$ & $\begin{array}{c}-1.483 * * \\
(0.679)\end{array}$ \\
\hline IRA*Competition Index & $\begin{array}{l}-1.170 \\
(1.286)\end{array}$ & $\begin{array}{l}-1.387 \\
(1.414)\end{array}$ & $\begin{array}{l}-2.468^{*} \\
(1.395)\end{array}$ & $\begin{array}{l}1.836^{*} \\
(1.005)\end{array}$ & $\begin{array}{c}2.019 \\
(1.377)\end{array}$ & $\begin{array}{l}-0.414 \\
(2.346)\end{array}$ \\
\hline Population density & $\begin{array}{c}0.149 * \\
(0.0815)\end{array}$ & $\begin{array}{c}0.156 \\
(0.103)\end{array}$ & $\begin{array}{c}0.117 \\
(0.0983)\end{array}$ & $\begin{array}{l}-0.0137 \\
(0.0537)\end{array}$ & $\begin{array}{c}-0.142 \\
(0.0970)\end{array}$ & $\begin{array}{c}0.273 * * \\
(0.131)\end{array}$ \\
\hline GDP per capita & $\begin{array}{r}0.588 * * * \\
(0.0480) \\
\end{array}$ & $\begin{array}{r}0.864 * * * \\
(0.0712) \\
\end{array}$ & $\begin{array}{r}0.208 * * * \\
(0.0710) \\
\end{array}$ & $\begin{array}{r}0.237 * * * \\
(0.0573) \\
\end{array}$ & $\begin{array}{l}0.253^{*} \\
(0.141) \\
\end{array}$ & $\begin{array}{c}-0.122 \\
(0.0869) \\
\end{array}$ \\
\hline Observations & 205 & 203 & 159 & 172 & 149 & 158 \\
\hline $\begin{array}{l}\text { Note. Robust standard errc } \\
\text { "total natural resources ren } \\
* * * \mathrm{p}<0.01, * * \mathrm{p}<0.05, * \mathrm{p}\end{array}$ & $\begin{array}{l}\text { in parentheses. V } \\
\text { of GDP)" and "in } \\
\text { (...) means are no }\end{array}$ & $\begin{array}{l}\text { bles used as instru } \\
\text { ndence year from } \\
\text { orted. }\end{array}$ & $\begin{array}{l}\text { ents are "The Polity IV } \\
\text { lonization". Year dum }\end{array}$ & $\begin{array}{l}\text { emocracy indic } \\
\text { ies and constan }\end{array}$ & $\begin{array}{l}\text { r", "Legal origin } \\
\text { erms are not repo }\end{array}$ & dimmy variable", \\
\hline Three-way interaction & $\begin{array}{c}-0.380^{* * *} \\
(0.146)\end{array}$ & $\begin{array}{c}0.335 \\
(0.257)\end{array}$ & $\begin{array}{c}0.951 * * * \\
(0.205)\end{array}$ & $\begin{array}{c}0.661 * * * \\
(0.221)\end{array}$ & $\begin{array}{l}0.828 * * * \\
(0.280)\end{array}$ & $\begin{array}{l}-0.152 \\
(0.237)\end{array}$ \\
\hline Population density & $\begin{array}{l}0.189 * * * \\
(0.0295)\end{array}$ & $\begin{array}{l}0.220 * * * \\
(0.0727)\end{array}$ & $\begin{array}{c}-0.103 \\
(0.0654)\end{array}$ & $\begin{array}{c}-0.102 \\
(0.0676)\end{array}$ & $\begin{array}{l}-0.227 * * \\
(0.0917)\end{array}$ & $\begin{array}{l}0.208 * * * \\
(0.0564)\end{array}$ \\
\hline GDP per capita & $\begin{array}{r}0.563 * * * \\
(0.0271)\end{array}$ & $\begin{array}{l}0.814 * * * \\
(0.0549)\end{array}$ & $\begin{array}{l}0.165 * * * \\
(0.0384)\end{array}$ & $\begin{array}{l}0.251 * * * \\
(0.0514)\end{array}$ & $\begin{array}{r}0.307 * * * \\
(0.0950)\end{array}$ & $\begin{array}{l}-0.100 * * \\
(0.0506)\end{array}$ \\
\hline Observations & 205 & 203 & 159 & 172 & 149 & 158 \\
\hline
\end{tabular}

Note. Robust standard errors are in parentheses. Variables used as instruments are "The Polity IV democracy indicator", "Legal origin dummy variable", "total natural resources rents (\% of GDP)" and "independence year from colonization". Year dummies and constant terms are not reported.

$* * * \mathrm{p}<0.01, * * \mathrm{p}<0.05, * \mathrm{p}<0.1$. (...) means are not reported. 